\title{
THE EVOLVING IMPACTS OF THE COVID-19 PANDEMIC ON GENDER INEQUALITY IN THE U.S. LABOR MARKET: THE COVID MOTHERHOOD PENALTY
}

\author{
Robert W. Fairlie \\ Kenneth Couch \\ Huanan $\mathrm{Xu}$ \\ Working Paper 29426 \\ http://www.nber.org/papers/w29426
NATIONAL BUREAU OF ECONOMIC RESEARCH
1050 Massachusetts Avenue
Cambridge, MA 02138
October 2021

We received no funding for this research project. The views expressed herein are those of the authors and do not necessarily reflect the views of the National Bureau of Economic Research.

NBER working papers are circulated for discussion and comment purposes. They have not been peer-reviewed or been subject to the review by the NBER Board of Directors that accompanies official NBER publications.

(C) 2021 by Robert W. Fairlie, Kenneth Couch, and Huanan Xu. All rights reserved. Short sections of text, not to exceed two paragraphs, may be quoted without explicit permission provided that full credit, including $\left({ }^{\circ}\right.$ notice, is given to the source. 
The Evolving Impacts of the COVID-19 Pandemic on Gender Inequality in the U.S. Labor Market: The COVID Motherhood Penalty

Robert W. Fairlie, Kenneth Couch, and Huanan Xu

NBER Working Paper No. 29426

October 2021

JEL No. J16

\section{ABSTRACT}

We explore whether COVID-19 disproportionately affected women in the labor market using CPS data through the end of 2020. We find that male-female gaps in the employment-topopulation ratio and hours worked for women with school-age children have widened but not for those with younger children. Triple-difference estimates are consistent with most of the reductions observed for women with school-age children being attributable to additional child care responsibilities (the "COVID motherhood penalty"). Conducting decompositions, we find women had a greater likelihood to telework, higher education levels and a less-impacted occupational distribution, which all contributed to lessening negative impacts relative to men.

Robert W. Fairlie

Department of Economics

Engineering 2 Building

University of California at Santa Cruz

Santa Cruz, CA 95064

and NBER

rfairlie@ucsc.edu

Kenneth Couch

University of Connecticut

Kenneth.Couch@uconn.edu

\section{Huanan Xu}

Judd Leighton School of Business

and Economics

Indiana University South Bend

huanxu@iu.edu 


\section{Introduction}

The economic downturn attributable to the social distancing measures and reductions in economic demand due to the emergence and spread of COVID-19 might have affected women and men differently in the labor market. An important and pressing question is whether women have been disproportionately affected by COVID-19 due to child caregiving demands and being concentrated in jobs impacted the most by "nonessential" business closures and remote work flexibility. This paper provides evidence on the effects of the pandemic recession on labor market outcomes among prime-aged women and men covering the first three quarters since state level social distancing measures were widely adopted in March of 2020 to slow the spread of the disease. The first three quarters are important in that they cover the initial unexpected adjustment period, the summer when schools were out of session but workers were starting to go back to their jobs, and the return to school in the fall for children (although mostly at home).

The increased integration of women into the U.S. labor market over the past 60 years has mobilized a major economic resource for the nation. Technological changes that reduced the necessary time for housework and enabled effective control of fertility along with legal reforms that changed the division of assets following divorce altered the choices available to women and changed the shapes of their lives (Juhn and McCue 2017). Gaps in labor market behavior between men and women narrowed over successive age cohorts progressing towards convergence of all measures of labor market activity through direct investment in skills and the choice to delay childbearing and reduce family sizes to also invest in careers (Goldin and Mitchell 2017). Despite this progress disparities in labor market experiences associated with childbearing are visible in lifecycle data on women's labor supply and are a driving factor in remaining male-female wage inequality. Difficulty in access to and the affordability of child care is typically identified as an 
important detriment to labor market participation and advancement for women in the United States (Blau and Kahn 2013a, Goldin and Mitchell 2017, Juhn and McCue 2017, Waldfogel 1998). Further, the lack of flexibility on the part of employers and their customers in having access to employee services at specific times is seen as a driver of gender gaps in work and pay across occupations (Blau and Kahn 2013a, Goldin 2014).

Has the unprecedented closure of schools and childcare facilities throughout the country due to the pandemic disrupted the progress women have made in the labor market and exacerbated disparities related to having children? A key concern is the impact of additional childcare responsibilities on the labor market experiences of women due to COVID-19 for single mothers and possible disproportionate responsibilities for married mothers (the "COVID motherhood penalty"). This paper provides a detailed analysis of the impact of different child care burdens across families on reduced labor market activity of women in the context of the coronavirus pandemic. We examine women with different age groups of children because of implications for child caregiving demands both expected and unexpected during the pandemic. We compare trends in female and male labor market outcomes across child age groups and estimate difference-indifference, triple-difference and event-study models to isolate impacts due to increased child caregiving demands in the first three quarters after the adoption of statewide closures of nonessential businesses in March of 2020.

Although increased caregiving may have disproportionately impacted women during the pandemic, an additional concern is that the types of jobs held and human capital levels of women might have also placed them at higher risk of negative labor market outcomes relative to men from COVID-19. Direct levels of skill such as education and potential workplace experience along with differential concentrations in industries and occupations might explain gaps between men and 
women in any downturn. Of particular interest, however, due to the imposition of social distancing restrictions at the state level that typically included the physical closure of non-essential businesses is the existing concentration of female relative to male employment in those industries as well as in jobs that cannot be performed remotely or were related to greater exposure to illness. Were women more concentrated in the types of jobs that were hit the hardest by COVID-19 (e.g., services), or were women less concentrated in those jobs partly insulating them from losses (e.g., construction, manufacturing and transportation)? Decomposition methods are used to provide estimates of the relative contributions of female-male differences in essential industries, ability to work remotely, skills, potential experience, and job types to gender gaps in the labor market in the pandemic. Findings from these decompositions combined with the difference-in-difference and triple-difference models provide comprehensive evidence on whether women were disproportionately impacted by COVID-19 due to differential job types, human capital and child caregiving demands.

Using CPS data for the first nine months of the pandemic after the widespread implementation of social distancing restrictions, we find that the employment-to-population ratio fell more for all women ages 25 to 55 than for comparable men; however, women without children for the most part did not experience changes that were distinguishable from those for men without children. The disproportionate reductions in employment for women occurred among those with school-age children in comparison to men with school-age children. Employment among women living in families containing only school-age children dropped substantially relative to men in the first few quarters of the pandemic (ranging from 2.3 to 4.3 percentage points). Triple-difference estimates indicate that women with school-age children experienced disproportionately large 
reductions in employment in comparison to women without children and that a large portion of these changes can be attributed to reductions in work activity due to the presence of their children.

Exploring impacts on hours worked which capture both changes in employment and reductions from full-time to part-time work, we again find that women living in families with only school-age children suffered especially large losses in hours worked relative to men (8 to 27 percent). In triple-difference models, reductions in hours are found to be concentrated among women with all their children ages 6-17 relative to those with no children present and that a large portion of this reduction is likely attributable to additional child care responsibilities. In combination, these results for the employment-population ratio and hours worked are consistent with the unexpected arrival of school-age children at home due to the pandemic which resulted in increased home-based caregiving demand that disproportionately reduced women's work activity.

Examining job and skill characteristics associated with gaps in unemployment between women and men reveals interesting patterns. Nonlinear decomposition estimates indicate that many job and skill characteristics were favorable for women in the pandemic lessening potential negative impacts relative to men. In particular, women were more concentrated in jobs that can be done remotely, were more concentrated in favorable occupations, and have higher education levels than men. However, women were more likely to work in "non-essential" industries than men prior to the pandemic which served to widen the unemployment gap through the Spring and Summer of 2020.

The findings from our paper contribute to a rapidly growing literature on the early-stage impacts of COVID-19 on the labor market outcomes of women. One of the first studies, Alon et al. (2020) argued that the closures of non-essential businesses and the lack of the ability to telework would likely drive male-female differences in labor market outcomes by using data on work 
patterns prior to the pandemic. Setting the stage, they argued that if prior patterns held, women would likely face hard choices between working when possible or caring for children at home, which would ultimately be expected to contribute to observed reductions in women's employment in the pandemic. Montenovo et al. (2020) make use of CPS data through April 2020 and find that traditional factors such as occupational distributions help explain cross-group differences in employment and that ability to work remotely plays a role. They report that employment fell slightly more among women than men and for those in families with large numbers of children. Holder, Jones and Masterson (2021) also use CPS data through April 2020 and find that COVID19 related job losses hit industries in which Black women were concentrated the hardest. Similarly, Collins et al. (2020) make use of CPS data from February through April 2020 and examine changes in work hours for men and women in married heterosexual couples who remain continuously employed for those months. They find that work hours declined more for women than men particularly for those with young children and that the ability to telework did not eliminate this pattern. Alternatively, Heggenes (2020) focuses on the impact of early school closures on parents with children present under the age of 18 using April through May 2020 CPS data. Examining a range of labor market outcomes, the early shutdowns had a negative impact for women for the employment outcome, "have a job but not be working," but did not have an immediate impact on detachment or unemployment. Bartik et al. (2020) report that women were more likely to stop work in April and less likely to start work in May and June using CPS data. Finally, Albanesi and Kim (2021) find that reductions in employment through November 2020 were concentrated among women with children and was similarly associated with movement of women out of the labor force.

Surveys provide direct evidence that mothers carried a heavier load in the provision of childcare in the early stages of the pandemic than fathers. For example, the Understanding 
Coronavirus in America tracking survey provides information through July on which parent is primarily responsible for providing care while schools were closed and clearly shows that there was a disproportionate burden among women (Zammaro and Prados 2021; Kapteyn et al. 2020). Focusing on academia, Deryugina, Shurchkov and Stearns (2021) conduct a global survey of academics and find that although both women and men report substantial increases in childcare and housework burdens, women, especially those with young children, experienced a disproportionate reduction in time dedicated to research.

Our paper builds on this literature in several important ways. First, we extend these early analyses by examining a longer time period observing impacts of the coronavirus using CPS micro-data through December 2020. The labor market experiences of women and men might have evolved differently over the pandemic from unanticipated changes in the beginning, to patterns over the summer, to the expected return to school in the fall. Here, we investigate longer term impacts of the pandemic and find that as the reductions in demand and loss of accommodations for children in schools and daycare continued that the disproportionate impact on women increased. Second, we provide a broad view of the types of families considered by examining cohabiting, single and married parents. Third, we expand on the range of labor market outcomes considered. In particular, we allow individuals to exit the labor market by focusing primarily on the employment-to-population ratio and unconditional hours worked. Finally, we add to the analysis of employment reductions due to increased child care responsibilities by also estimating the impacts due to differences in job and skill characteristics providing a more comprehensive study of both influences in the pandemic.

\section{Context and Analytical Approach}


The diagnosis of the first case of COVID-19 in January 2020 in the United States and the rapid evolution of school closures and business restrictions was a truly unanticipated event. By the end of March 2020 all states had adopted some social distancing measures which typically included closure of non-essential businesses and movement of primary and secondary schools to remote instruction. The unusual pattern of economic disruption from COVID-19 interacted with the long-term trend of increasing engagement of women in the labor market. In the past, as family sizes declined and education levels of women increased, competing demands for time at home decreased while the rewards from the labor market increased. Labor force participation and average hours of work have increased at every age until the most recent cohorts (Goldin 2014, Goldin and Mitchell 2017). Nonetheless, over the lifecycle of women within a cohort, reductions in work activity typically occur with the arrival of children. Arrival and presence of children is also associated with the male-female wage gap in part due to reduction in formation of specific human capital during intensive periods of child care and possible absence from the labor market (Juhn and McCue 2017).

Accordingly, we focus on the employment-to-population ratio among women as an important indicator of their labor market activity while providing supportive estimates of hours of work unconditional on employment. Hours of work captures additional potential impacts from movement from full-time to part-time work. In ordinary times, families must make child care plans that evolve with the age of the child. Pre-school children require different care than school-age children and those demands typically decline with their age. Labor market interruptions for women most often are associated with child birth. Thus, we focus on differential experiences for women in families with no children, any children, young children, or school-age children as day care and school closures would be expected to have different impacts for these groups (Juhn and McCue 
2017, Collins et al. 2020). To provide the basis for inferring the changes being estimated within the difference-in-difference models arose due to the pandemic, we also estimate event-history models showing that the models effectively eliminate pre-pandemic differences across comparable groups of men and women.

After examining the impact of COVID-19 on the employment of these different groups of women relative to men, we also estimate triple-difference models of the differences in employment across women who face different caregiving demands. Nonlinear decomposition methods are then used to explain the contribution of different factors to female-male unemployment gaps during the pandemic. Both personal skills and factors unique to this downturn such as employment in essential industries, the ability to work remotely, and occupational risk of exposure to disease are examined. The contribution of the distribution of employment across occupations and industries to the unemployment gap between women and men is also considered.

\section{Data and Measures}

The data used in the analysis are drawn from the basic monthly files of the Current Population Survey (CPS). The CPS is the primary monthly household survey used to derive national labor statistics for the United States. The data are collected in a reference week containing the $12^{\text {th }}$ of the month. The survey gathers information on the members of 60,000 households and when weighted the data represents the civilian non-institutional population ages 16 and older of the United States.

As our interest is in estimating the impact of the COVID-19 pandemic on the labor market activity of women and men, we note that some social distancing measures including local closures of businesses and schools occurred just prior to the collection of March CPS data. All states, 
however, put in place at least some level of social distancing measures prior to the collection of April CPS data. Thus, we view the March data as a month partially impacted by the pandemic and April as being the first month in which labor market activity was disrupted throughout the country.

In the analysis, we make use of the basic monthly public release CPS data files beginning several years prior to the pandemic in 2017 and extending through December of 2020 . We focus on changes in employment experiences beginning with April 2020 given the timing of the adoption of social distancing restrictions nationally. We combine data across months in much of the analysis, referring to post-COVID periods as Spring, Summer and Fall. ${ }^{1}$ February 2020 is used as the reference, pre-pandemic month.

We make use of family structure information within the CPS to identify working- and child rearing-age adults (ages 25-55) with and without children at home. Using information on the age of children who are present in the household, we also identify families with different ages of children. $^{2}$

\section{Measures Related to COVID-19}

In the context of the pandemic, we make use of several measures that potentially capture the influence of physical closures of non-essential businesses, the ability of people to work remotely, and the risk of disease exposure on the job. With respect to measuring whether a person was employed in an essential or non-essential business, we use coding based on Delaware state standards which employ the North American Industry Classification System (NAICS). ${ }^{3}$ This

\footnotetext{
${ }^{1}$ April and May 2020 are included in the Spring, June to August 2020 included in the Summer, and September to December 2020 in the Fall.

${ }^{2}$ We also considered estimates stratified by number of children present rather than the ages of children. The main part of the effects shows up with having one child and not as an increasing function in the number of children. The fixed cost of having one child at home on women's labor supply may be more important than the incremental cost of having additional children at home.

${ }^{3}$ See https://coronavirus.delaware.gov/resources-for-businesses/.
} 
variable is coded at the 4-digit level of industry classification. Similarly, we make use of a measure developed by Dingel and Neiman (2020) of the ability of a worker to perform work remotely. Their index is based on 15 underlying O*NET (Occupational Information Network) questions. Finally, we use a measure of exposure to disease or infection also developed from an O*NET question asking "How often does your current job require you be exposed to diseases or infections?" (Baker et al. 2020). Those responses are transformed into a Z-score with mean 0 and standard deviation 1.

\section{Descriptive Patterns of Male and Female Employment}

Figures 1 and 2 display female and male employment-to-population ratios and hours of work from January 2017 to December 2020. To focus on both working-age and child-rearing adults we include only women and men ages 25-55. As can be seen in the figures, prior to the adoption of widespread social distancing measures due to the coronavirus in March of 2020, systematic gaps are evident between men and women. With respect to the employment-to-population ratio (Panel A of Figure 1) the average rate of employment among men was roughly 86 percent whereas the average rate of employment among women was roughly 73 percent. The employment-topopulation ratio among women without children was a bit higher (about 76 percent) and a bit lower (about 70 percent) among women with children. From February to April 2020, the employmentto-population ratio visibly drops across all groups. The pace of recovery in the subsequent months, based on the figure, appears to be fairly comparable across the group of all men and those of women; however, these overall patterns may mask heterogeneous impacts if women are compared directly to men in the same family situation and job type. 
Panel B of Figure 1 shows a similar pattern for average hours of work for the same groups. Prior to the widespread implementation of social distancing measures in March 2020, average hours of work were largest for men followed by women without kids, the group of all women, and women with kids. From February to April 2020, average hours of work fell sharply and by similar amounts (6 to 7 hours) across all groups. As the economy began to gradually reopen in the following months, the recovery in average hours of work appears to have been a bit more rapid for men than for women.

Figure 2 provides trends in employment and hours of work for more detailed breakdowns by age of children. In Panel A, women with all of their children ages 14-17 have the highest employment-to-population ratios followed by those with only children ages 6-13, and those with their children between ages 0-5. With the arrival of the pandemic, all women experienced a sharp decrease in employment; however, there is clear variation across groups. For women with children ages $0-5$, the decline in the employment-to-population ratio was by 10 percentage points whereas the decline was by roughly 12 percentage points for women with children ages 6-13 and women with children ages 14-17. It also appears that employment recovered more slowly for groups with school-age children through the end of 2020. These raw trends are consistent with parents who had school-age children experiencing increased demands on their time for caregiving when previously these children were in school.

Panel B of Figure 2 provides the same breakdowns for average hours of work for women with children of different ages. Average hours of work are again consistently ordered over time with women with children ages 14-17 having the highest average hours followed by women with children ages 6-13 and women with children ages 0-5. From February to April 2020, hours of work fell by similar amounts across all groups ( 5 to 7 hours). In the fourth quarter of 2020 , when schools 
would have reopened in many locations, hours worked by women with school-age children appear to increase at a somewhat faster rate than for women with children ages 0-5; however, average hours worked for all groups remained below levels immediately preceding the pandemic.

To examine whether women with children are making more of an adjustment to accommodate disruptions due to COVID-19 that have led to their children unexpectedly being at home, we compare their work activity to men in the same family setting. We do this descriptively in Tables 1 and 2 which examine changes in the employment-to-population ratio and average hours of work, respectively. We combine months to examine three seasons, Spring 2020, Summer 2020 and Fall 2020, which approximate the timing of i) unanticipated disruptions to school, ii) disruptions to summer camps and plans, and iii) more anticipated disruptions to school, respectively. ${ }^{4}$ We also focus the analysis on families with solely school-age children versus younger children to draw clearer distinctions in demands for caregiving. Starting with adults with no children in February 2020 (Panel B of Table 1), the employment-to-population ratio was 81.7 percent for men and 77.1 percent for women (male-female gap of 4.6 percentage points). In the Spring of 2020 where the effects of the pandemic could be clearly measured, the employment-topopulation ratio fell to 71.6 percent for men and 66.4 percent for women (male-female gap of 5.2 percentage points). In Summer 2020, the gender gap remained at a similar level of 5.4 percent. In Fall 2020, the employment rate of women without children increased more rapidly than that of men, narrowing the gender gap back to 4.6 percent (although employment rates of both women and men remained beneath their pre-pandemic levels).

\footnotetext{
${ }^{4}$ The post-COVID periods are April through December 2020. Spring includes April and May; Summer includes June to August; Fall includes September to December. We do not report March 2020 in Tables 1 and 2 because it was only partially affected by COVID-19 (Couch, Fairlie and Xu 2020).
} 
Women without children are most similar to men in their labor market participation patterns. We turn to a comparison between all men and women with children (Panel C of Table 1). In February 2020, the employment-to-population ratio was 91.3 percent for men and 71.9 percent for women, with a male-female gap of 19.4 percentage points. In the Spring, the employment-topopulation ratio fell for both groups but disproportionately for women, widening the male-female gap to 22.0 percentage points. Through the remainder of the year, the gender gap remained roughly the same in the Summer and narrowed to 21.3 percent in the Fall, but remained larger than in February 2020.

The descriptive information for employment differences between women and men with children ages 0-5 and with children ages 6-17 are reported in the next two panels of Table 1. The patterns are similar to those for all women with children. Relative to February 2020, Spring 2020 indicates a widening of the male-female gap in the employment-to-population ratio. The initial disproportionate losses in female employment from February to the Spring are larger among those with school-age children (6-17 ages). In the Fall, the employment gaps remain larger than in February 2020. Also, employment rates are lower among men and women in the Fall than they were in February.

A similar pattern is evident in examining hours of work which captures both changes in employment and reductions in hours on the job (reported in Table 2). Considering adults with no children present in February 2020 (Panel B of Table 2), men worked an average of 32.9 hours per week and women worked an average of 29.3 hours per week, implying a male-female gap of 3.6 hours per week. Immediately after the pandemic started (Spring 2020), hours of work fell to 26.7 hours for men and 23.2 hours for women. The decreases are similar in magnitude leaving the gender gap in hours of work mostly unchanged. In the summer, the gap widened to 4.6 hours as 
work activity began to resume out of the pandemic. However, during the Fall, the average gap again declined back down to pre-pandemic levels (at 3.3 hours). Although the gender gap in hours of work returned to pre-pandemic levels in Fall 2020 average hours of both men and women were still below pre-pandemic levels.

Considering those with school-age children and using February 2020 (Panel E of Table 2) men worked 38.1 hours on average while women worked 27.6 hours with a gap of 10.5 hours. During the Spring of 2020, average hours of men and women fell by similar amounts, slightly widening the gap in hours worked to 10.7 hours. However, as economic activity began to expand in the summer months, the male-female gap widened to 12.4 hours. During the Fall, hours of work increased for both groups and the gap narrowed to 10.8 hours. Relative to pre-pandemic levels, the male-female gap in hours worked at the end of 2020 was similar although average hours worked for both groups were at lower levels.

In summary, relative to months just prior to the pandemic, all women with children on average had larger reductions in employment and hours of work than comparable men during the summer when children would have been home from school. Descriptively, this resulted in a widening of male-female gaps in labor market outcomes during the summer concentrated among women with school-age children. Those decreases in employment and hours of work appear to have at least temporarily erased some of the longer-term convergence between women and men.

\section{Methodology}

To better gauge experiences between comparable women and men, and control for preCOVID trends, we estimate difference-in-difference models. The form of the equation estimated is: 
(V.1) $Y_{i t}=\alpha+\gamma$ Female $_{i}+\sum_{q=1}^{3} \pi_{q} \operatorname{COVID}_{q}+\sum_{q=1}^{3} \delta_{q}$ Female $_{i} *$ COVID $_{q}+\beta^{\prime} X_{i t}+\lambda_{t}+$ $\theta_{t}+\tau+$ Female $* \tau+\varepsilon_{i t}$

where $Y_{i t}$ is one of the two outcomes being examined, (1) the employment-to-population ratio, $E_{i t}$, or (2) hours of work per week, Hours ${ }_{i t} . E_{i t}$ is a categorical indicator of whether a person is employed or not in month t. Hours $i t$ is the log of weekly working hours including not working (i.e. zero hours) and capped at 60 hours. ${ }^{5}$ Female $_{i}$ is a categorical indicator coded with a value of one for women in the sample. $\operatorname{COVID} D_{q}$ is a dummy variable for each post-COVID quarter beginning with Spring (April to May) through Summer (June to August) and Fall (September to December) of $2020 .{ }^{6}$ March 2020 is included in the sample, but not reported in the tables because of potentially misleading estimates associated with a partially COVID-19 impacted month. ${ }^{7} X_{i t}$ includes personal characteristics for each individual in month t. The sample period includes January 2017 to December 2020 to allow for the inclusion of seasonal (monthly) fixed effects, $\lambda_{t}$, year fixed effects, $\theta_{\mathrm{t}}$, and a time trend, $\tau$, (as well as a female specific time trend). ${ }^{8} \varepsilon_{\mathrm{it}}$ is the error term.

We estimate Equation (V.1) for all women and men, women and men with young children (ages 0-5), women and men with school-age children (ages 6-17), and other permutations of these groups. The separate samples provide evidence on how different groups were impacted after

\footnotetext{
${ }^{5}$ Hours are transformed with inverse hyperbolic sine to approximate $\operatorname{logs}$ and include zero hours. The inverse hyperbolic sine transformation is given as: $\sinh ^{-1}($ Hours $)=\ln \left(\right.$ Hours $\left.+\sqrt{\text { Hours }^{2}+1}\right)$

${ }^{6} \mathrm{We}$ also conduct the analysis using post-COVID month dummies instead of the quarter indicators. Results are similar and are shown in Appendix Table A.1. (difference-in-difference estimates) and Table A.2 (triple-difference estimates).

${ }^{7}$ We include a full set of interactions for March. Findings are robust to the exclusion of March 2020 data.

${ }^{8}$ Estimates are robust to including quadratic and cubic trends and interactions.
} 
controlling for differences in individual characteristics (e.g., education level, marital status and geographical location) as well as pre-existing trends in outcomes for women and men.

We expand on Equation (V.1) to include annual pre-COVID dummies for an event-study regression. Equation (V.1) already allows for differential post-COVID effects by season. For the event-study regression we interact the categorical variables for each year prior to the pandemic during the sample period with the female variable. We again use February 2020 as the pre-COVID reference point in time. We report the resulting parameter estimates and 95 percent confidence intervals in figures.

To directly examine the impact of the presence of children of different age groups we estimate triple-difference models. The triple-difference model of the impact of COVID-19 and the presence of children of different ages in the household on the female-male gap is:

(V.2) $Y_{i j t}=\alpha+\gamma$ Female $_{i}+\sum_{q=1}^{3} \pi_{q}$ COVID $_{q}+\varphi$ Child $_{j}+\delta_{1}$ Female $_{i} *$ Child $_{j}+$

$\sum_{q=1}^{3} \delta_{2 q}$ Female $_{i} *$ COVID $_{q}+\sum_{q=1}^{3} \delta_{3 q}$ COVID $_{q} *$ Child $_{j}+\sum_{q=1}^{3} \delta_{4 q}$ Female $_{i} *$ COVID $_{q} *$

Child $_{j}+\beta^{\prime} X_{i j t}+\lambda_{t}+\theta_{t}+\tau+$ Female $* \tau+\varepsilon_{i j t}$

where Child $_{j}$ is a set of dummy variables for the presence of children of different ages (1 for any children ages $0-5$, any children ages 6-17, only children ages $0-5$, only children ages 6-17, respectively; 0 for no presence of children). Other model specifications are the same as in equation (V.1).

\section{Difference-in-Difference Estimates Relative to Men}

Employment-to-Population Ratio 
Table 3 Panel A contains estimates for the employment-to-population ratio for the full sample of women and men ages 25-55. The first column of estimates shows that the pandemic downturn resulted in a statistically significant widening of the overall male-female gap in the Spring and Summer post-Covid periods of about 1 percentage point. Relative to February 2020, no widening of the gender gap is observed in Fall 2020.

Column (2) reports estimates for women without children relative to men without children. The difference-in-difference estimates indicate that the male-female gap in employment was statistically unchanged relative to February 2020. Thus, when controlling for a variety of personal characteristics and pre-existing trends, the experiences of women without children appears to be comparable to that of men without children. We use this comparison later as the baseline for our triple-difference estimates that focus on the potential impacts of differential child-rearing responsibilities.

Column (3) reports estimates for women with any children relative to men with any children, and indicates that the male-female gap in employment increased substantially in all three post-Covid periods relative to February 2020. These estimates, however, conceal important differences by age of children. Columns (4) and (6) consider families with young children (ages 0-5). Column (4) measures the presence of young children while allowing for other children to be present. Column (6) considers families with only children ages 0-5. No significant estimates of the pandemic on the relative employment of men and women are seen in the three post-Covid periods of 2020 for families with children in this age group.

Columns (5) and (7) consider families with school-age children present. Column (5) focuses on families with any school-age children, and Column (7) focuses on families with only school-age children. In column (7), all of the estimated impacts show statistically significant 
increases in the gender gap in the employment-to-population ratio in the post-Covid periods. The largest estimate ( 4.3 percentage points) is found in the summer months, but widened gap is still substantial in the Fall of 2020 at 2.3 percentage points. In Column (5), the estimates for the three post-Covid periods are also statistically significant and the widened gap in the Summer appears somewhat larger (2.7 percentage points) than in the Spring immediately following the imposition of state level social distancing measures (2.4 percentage points). The estimates among families with only school-age children are consistently larger across all three seasons than for those who may also have other children. Hence, the strongest evidence of a reduction in women's employment relative to that of men is found in families with school-age children, especially those who did not also have younger kids present. This is consistent with women in families who had all children engaged with school having to reduce employment to meet child care demands as children came home for online instruction. Women and men in families with only younger children at home might have been less disrupted by the pandemic because their children were not enrolled in school.

\section{Hours of Work}

Panel B of Table 3 reports estimates of the change in total hours worked per week among women and men (i.e., unconditional on working) in the pandemic. The coefficient estimates can be interpreted as percentage changes relative to February 2020. The overall pattern of results is similar to those for the employment-to-population ratio. The estimates indicate that the overall female-male gap in hours of work widened by about 11 percent in the Summer of 2020. However, no statistically significant change in the gender gap is observed in the Fall. Estimates for women without children reveal a statistically significant change in the female-male gap in hours worked 
only during the Summer of 2020. In the Fall, no statistically significant change in the gender gap is observed.

Focusing on either families with any young children ages 0-5 (Column 4) or families with only young children (Column 6), no statistically significant estimates of the response of hours of work of women relative to men are found. However, the estimates in Column (5) show a statistically significant reduction in hours of work of women relative to men of 18.3 percent in the Summer of 2020 when any children ages 6-17 are present. The estimated parameters in Column (7) focusing on families with only school-age children are statistically significant over the three post-Covid periods of 2020 , ranging from about 8 percent to 27 percent. The impact was noticeably larger in the Summer than in the Spring or Fall. The estimates for hours of work are consistent with those for the employment-to-population ratio in showing that the largest response was for women in families who prior to disruption caused by the pandemic had all of their children placed at school during typical weekdays. ${ }^{9}$

\section{Event-Study Regressions}

We also expand on the difference-in-difference regressions to include annual pre-COVID dummies for an event-study regression. We already allow for differential post-COVID effects by season (i.e., Spring, Summer and Fall of 2020), but now we also allow for pre-COVID annual differences for women relative to men. Estimates for the employment-to-population ratio and hours of work are reported in Figures 3 and 4 respectively. We focus here on key estimates for the paper highlighting results for women with no children, those with any children ages 6-17, and

\footnotetext{
${ }^{9}$ For both the difference-in-difference and triple difference estimates, we explored whether patterns of statistical significance for the employment-to-population ratio or hours of work would be affected by clustering standard errors by state. Clustered standard errors do not impact patterns of significance across family types or inferences drawn in the study.
} 
those with only children ages 6-17. Figure 3 shows that for these groups there are no significant differences for female-male gaps in employment in the three years prior to the pandemic when measured relative to time zero, February 2020. Figure 4 shows this same result for hours of work unconditional on employment status. These models and results are both quantitatively and qualitatively comparable to those in Table 3 for the difference-in-difference models. ${ }^{10}$

\section{Hours Conditional on Working}

To further investigate the potential effects of the pandemic on hours of work we estimate regressions that condition on working. We explore whether hours of worked were affected more for women than for men in the pandemic among those who continued to work. Thus, we drill down with the hours analysis to focus on the intensive margin instead of the extensive margin captured by the employment regressions. We report these estimates in Appendix Table A.3. We find that there are no negative statistically significant estimates for hours of work for any group of women relative to men. This reveals that the disproportionate negative impact of the pandemic on the employment of women with children occurred primarily through employment exits rather than from reducing hours of work. We return to our focus on hours worked not conditioning on being employed because we are trying to capture the total effects of the pandemic.

\section{Robustness Checks}

We check our main regression models for robustness by estimating additional sets of regressions. First, we alter the age ranges included in the sample from 25-55 to include women and men ages 20-55 and separately to include women and men ages 25-60. Second, we alter sample

\footnotetext{
${ }^{10}$ In the models with annual pre-period dummies, we also include a trend-squared and cubed term in the models.
} 
years to begin in 2016 or 2018 in comparison to the main specification which begins in 2017 . The results are robust to all of these alternative age and time period ranges. ${ }^{11}$

\section{Married Couples}

The primary sample used in the paper considers all women and men ages 25 to 55 . One implication is that the comparisons are being made between all women and men in different family structures. An alternative approach is to examine only married couples which focuses on situations in which the tradeoffs of child-rearing burdens between two adults takes place. ${ }^{12}$ Appendix Table A.5 provide estimates comparable to Table 3 reducing the primary sample to married adults. The estimates are roughly similar with disproportionate reductions in employment and hours of work occurring among women with school-age children.

For completeness we also estimate regressions using our sample of unmarried individuals and parents. Appendix Table A.6 reports estimates. We find that the disproportionate negative response of women to COVID in employment occur for those with only school-age children and in hours of work for those with either any or only school-age children. Thus, the pandemic appears to have similarly impacted labor market outcomes for women regardless of marital status.

\section{School Reopenings}

At the outset of the pandemic states were quick to close both non-essential businesses and schools. The evidence presented thus far is largely consistent with the disproportionate negative impacts of the pandemic on female labor market outcomes being driven by school-age children

\footnotetext{
${ }^{11}$ Results are available upon request.

${ }^{12}$ Married couples here references both opposite- and same-sex marriages.
} 
returning home due to school closures. Here, we explore the possible influence of states with faster returns to in-person instruction in explaining differential outcomes.

In this analysis we make use of a school reopening index developed by Burbio (2021). The index is based on monitoring of in-person instruction at a sample of school districts which are weighted to form state-level estimates. We focus on states reopening relatively quickly by using the index to identify the top quartile of states in terms of the percentage of instruction offered inperson versus other states. Estimates are reported in Appendix Tables A.7 (employment-topopulation ratio) and A.8 (unconditional hours of work). We find that across all family types that states that reopened more quickly had smaller estimated declines in women's labor market outcomes relative to men than those that opened more slowly.

\section{Triple-Difference Estimates of Changes Due to Presence of Children}

\section{Employment-to-Population Ratio}

To further isolate the effects of child caregiving responsibilities on labor market outcomes we estimate triple-difference models that directly compare the gender gap for women and men with children to women and men without children. Table 4 Panel A presents triple-difference estimates based on Equation V.2. The third, added difference, here is between women and men with children of different age groups and women and men without children. As shown in Column (1), all women with children experienced a relative reduction in employment across the successive post-Covid periods of 2.4, 2.2, and 2.3 percentage points. The group in Panel A for whom the presence of children is shown to widen the employment-to-population ratio more than for women with no children most clearly and consistently is for those in families who had school-age children present (ages 6-17). For those families with any school-age children (Column 3) estimates across 
the three successive post-Covid periods are $2.7,2.8$, and 1.9 percentage points. For those with only school-age children (Column 5), the coefficients across successive periods are somewhat larger at 3.7, 4.3 and 2.8 percentage points. The smaller effects in the Fall, are consistent with a lessened impact due to school reopenings.

\section{Hours of Work}

Panel B of Table 4 similarly reports triple-difference estimates for the portion of the female-male gap in average hours of work that can be attributed to the presence of children of different age groups. Again, the group of women for whom statistically significant estimates are found are for those with school-age children. The estimates in Column (5) for families that only have school-age children are statistically significant in all of the post-Covid periods. The estimates indicate relative losses of women's hours of 13.9,22.3 and 12.8 percent over the successive periods.

The triple-difference estimates for the effect of the pandemic on the employment-topopulation gap or hours of work between women and men in families with school-age children make a comparison to the gender gap for adults with no children. This nets out changes that might have occurred because of the pandemic independent of the presence of children. For example, the triple-difference parameters for women in families with only school-age children in Column (5), Panel A of Table 4 are -.037, -.043, and -.028 for the Spring, Summer and Fall, respectively. The difference-in-difference estimates for particular groups instead reveal the impact of the influence of the caregiving burdens faced by women relative to men in the same situation. For example, the difference-in-difference estimates for women in families with only children that are school aged in Column (7), Panel A of Table 3 are -.034, -.043, and -.023 for the Spring, Summer and Fall. Comparing the triple-difference parameters to those from the difference-in-difference reveals 
information about how much of the change in labor market outcomes associated with the pandemic is likely due to the presence of children versus other effects. In the example given here, this comparison suggests that demands associated with having only school-age children likely accounts for the majority of the observed widening in the female-male gap in the employment-to-population ratio and hours of work for this group.

\section{Hours Conditional on Working}

We also provide triple-difference estimates (Appendix Table A.4) of the response of hours of work conditioning the sample to include currently employed individuals to explore whether the larger adaptations of women to the pandemic occurred predominately on the intensive or extensive margin. Across the same groups considered in Table 4, we do not find any negative statistically significant estimates. This is consistent with the disproportionate impact of the pandemic on women's employment primarily occurring through reductions of employment.

\section{Explaining the Male-Female Gap in Unemployment Rates}

We turn to exploring whether the types of jobs held and skill levels of women placed them at higher or lower risk of negative labor market outcomes from COVID-19 relative to men. These factors may have contributed to the impacts of COVID-19 on gender gaps in addition to increased child caregiving by women. The closure of non-essential businesses and consumer shifts away from in-store purchases resulted in higher unemployment for jobs in many sectors. To what extent were women more or less concentrated in these jobs than were men?

Before turning to an analysis of the contribution of job types and skill levels, we note that the CPS primarily collects information on industry and occupation only for those who are in the 
labor force.$^{13}$ Information on occupation and industry are not available for those out of the labor force who did not work in the past 12 months. For our sample, occupation and industry information is only available for 3 percent of those out of the labor force. ${ }^{14}$ The lack of occupation and industry information for nearly all individuals who are out of the labor force rules out an analysis of the employment-to-population ratio. Thus, we narrow the focus to those in the labor force and unemployment as the labor market outcome.

\section{Differential Job and Skill Characteristics and Unemployment Risk}

To investigate whether various job, skill and regional characteristics place women at differential risk of unemployment in the pandemic, we first compare female and male distributions of these characteristics. Table 5 presents female and male distributions prior to the pandemic and the national unemployment rate in the pandemic for several characteristics. As would be expected due to state closure policies that arrived in March 2020, the unemployment rate since April 2020 has been remarkably high (at 16 percent) among those who worked in non-essential industries. The proportion of women working in non-essential industries was also substantially higher than for men (17.1 versus 11.8 percent). Thus, employment in those industries would be expected to increase the male-female gap in the unemployment rate since the onset of the pandemic.

Measured skills in terms of educational attainment are an important correlate of labor market outcomes. As shown in Table 5, men are more likely than women to be a high school dropout (8.8 versus 5.6 percent) or high school graduate (28.1 versus 21.2 percent). Women are more likely to complete higher levels of education than men such as college (28.2 versus 24.7) or

\footnotetext{
${ }^{13}$ The one exception is for those who are unemployed and looking for work but have not previously worked. For our sample, 3 percent of the unemployed who are looking for work have missing occupation and industry information.

${ }^{14}$ Even in April 2020, we find that only 6 percent of those out of the labor force have occupation and industry information.
} 
post-graduate degrees (17.3 versus 13 percent). These differences in educational attainment would be expected to narrow the unemployment gap between men and women in the pandemic.

Several industries in which men are concentrated experienced relatively high unemployment rates in the pandemic. For example, Construction and Transportation had relatively high unemployment rates since April 2020 (9.1 and 9.7 percent respectively) but also had much larger proportions of men than women employed in them prior to the pandemic. For example, 13.2 percent of men but only 1.6 percent of women worked in construction. Similarly, 8.1 percent of men and 3.0 percent of women worked in Transportation.

Two occupational categories that experienced lower than average unemployment since the onset of the pandemic are Management (4.5 percent) and Professional and Business Services (5.0 percent). Across these two occupations a notably larger combined proportion of women (48 percent) than men (38 percent) are employed in them. In areas like Services, though, which has experienced higher than average unemployment (14.9 percent), more women (19.3 percent) than men (12.8 percent) are employed. Construction, Production, and Transportation occupations have far more men employed in them than women and have relatively high unemployment rates (11.0, 10.0 and 12.6 percent, respectively). Overall, it appears as though differential occupational concentrations are leaning towards being favorable for women in the pandemic relative to men, however, it is difficult to tell.

Women also tend to be more concentrated in jobs where they can work remotely $(46.2$ percent) than men (33.1 percent). Women are also more likely to work in jobs that are exposed to disease or illness at work than men. ${ }^{15}$

\footnotetext{
${ }^{15}$ Although we report that higher than median levels of health risk are associated with higher unemployment rates relative to lower than median levels of health risk in Table 5, the relationship follows more of an inverted U shape pattern.
} 


\section{Decomposition of Female-Male Unemployment Gap}

We use a decomposition technique that allows us to estimate the separate contributions from differences between men and women in education, industry, occupation, and other characteristics to gender gaps in unemployment rates. Specifically, we decompose inter-group differences in a dependent variable into the portions due to different observable characteristics across groups (the endowment effect) and to different "prices" of characteristics of groups (see Blinder 1973 and Oaxaca 1973). The Blinder-Oaxaca decomposition of the female-male gap in the unemployment rate, $\mathrm{Y}$, can be expressed as:

$$
\text { (VIII.1) } \bar{Y}^{F}-\bar{Y}^{M}=\left[\left(\bar{X}^{F}-\bar{X}^{M}\right) \hat{\beta}^{F}\right]+\left[\bar{X}^{M}\left(\hat{\beta}^{F}-\hat{\beta}^{M}\right)\right]
$$

We focus on estimating the first component of the decomposition that captures contributions from differences in observable characteristics or "endowments." We weight the first term of the decomposition expression using coefficient estimates from a pooled sample of all groups (Oaxaca and Ransom 1994). Pooled coefficients are used to incorporate the full market response and not exclude any groups of the population. ${ }^{16}$

The contribution from gender differences in the characteristics can be written as:

$$
\text { (VIII.2) }\left(\bar{X}^{F}-\bar{X}^{M}\right) \hat{\beta}^{*}
$$

where $\bar{X}^{j}$ are means of individual characteristics of gender $j, \hat{\beta}^{*}$ is a vector of pooled coefficient estimates, and $j=F$ or $\mathrm{M}$ for female or male respectively. Equation (VIII.2) provides an estimate of the contribution of gender differences in the entire set of independent variables to the gender

\footnotetext{
${ }^{16}$ An indicator variable for women is included in the underlying regression.
} 
gap in unemployment. Separate calculations are made to identify the contribution of group differences in specific variables to the gap. Because unemployment is a binary outcome we use the related, popular non-linear decomposition technique (Fairlie 1999, 2005; Jann 2006). ${ }^{17}$

Table 6 reports estimates from the non-linear decomposition procedure. Column (1) reports the unemployment decomposition for the pre-COVID reference month (i.e., February 2020). Just prior to the pandemic, women had a lower unemployment rate than men. Women's distribution across occupations and their higher educational attainment were significant explanatory factors in February 2020, which lowered the female-male unemployment gap by about 0.6 and 0.2 percentage points, respectively.

Decomposition estimates for each post-Covid period starting in the Spring of 2020 are reported in Columns (2) through (4) of Table 6. With respect to factors unique to the pandemic, we find some evidence that being in a job where it was more likely to telework explains part of the unemployment gap in the Spring and Fall. ${ }^{18}$ The distribution of workers across industries and in essential industries became a significant explanatory factor for the widening gender gap in unemployment in the post-COVID period during the Spring and Summer explaining 0.95 to 0.40 percentage points of the gap. However, in the Fall, this factor narrowed the female-male unemployment gap by 0.40 percentage points. We examined disaggregated quarterly rates of unemployment to help understand this change and found that as rehiring began in the Fall of 2020, that women's unemployment in essential industries declined more rapidly than men's (See Appendix Figure A.1). We also found that the negative influence due to women's employment in leisure and hospitality industries was alleviated in the Fall of 2020 (See Appendix Figure A.2).

\footnotetext{
${ }^{17}$ For the following application, we find that estimates from the linear Blinder-Oaxaca decomposition are similar. ${ }^{18}$ Note that the included major occupation dummies are at the 2-digit level whereas the telework variable is defined at the 4-digit occupation level. After removing the occupation dummies we find that telework variable becomes stronger.
} 
Differences in potential experience also served to widen the gender gap between women and men throughout the sample period. Potential experience, commonly measured by subtracting years of education from age, is known to misstate actual gaps in experience (Blau and Kahn 2013b, Zveglich et al. 2019). As an alternative measure, we explored the use of an expected experience measure developed by Zveglich et al. (2019) and found that while it explained more of the gap before the pandemic, it was less explanatory than potential experience in the pandemic. ${ }^{19}$ This likely reflects changes in employment due to altered child care demands rather than actual job experience.

The occupational distribution for female workers served to lower the gap between women and men consistently across the post-COVID periods (by roughly one percentage point in the Spring but about the same magnitude in the Fall as in February). The greater educational attainment of women also served to reduce the female-male unemployment gap in each period beyond February (by roughly 0.6 and 0.5 percentage points in the Spring and Summer before declining in magnitude to roughly the February level in the Fall). Gender differences in exposure to health risks are found to be a statistically significant explanatory variable that serves to narrow the unemployment gap in the Spring but not during other periods. ${ }^{20}$ Overall, traditional determinants of cross-group differentials such as education, industry and occupation contribute in various ways to gender gaps in unemployment in the pandemic.

\section{Conclusion}

\footnotetext{
${ }^{19}$ Results are available upon request.

${ }^{20} \mathrm{We}$ can distinguish between the health risk and occupation contributions in the decompositions because the set of occupation dummy variables are at the 2-digit level whereas the health risk variable is constructed to have variation at the much more detailed 4-digit level. The decomposition estimates for the occupation contribution are robust to excluding the health risk variable. We also find that the decomposition estimates for the health risk contribution are robust to excluding the occupation dummies.
} 
The emergence of COVID-19 and its spread in the United States disrupted the labor market through the closure of essential businesses and reductions in demand as consumers avoided interpersonal contact in making transactions. The movement of schools to distance learning in the pandemic also meant children who might have been at school, in day care, or at summer camps were now spending full days at home creating additional child care demands on parental time. Have women been disproportionately affected by COVID-19 due to being concentrated in jobs impacted the most by "nonessential" business closures and increased child caregiving demands?

The impacts from the pandemic can first be directly measured in the April 2020 CPS data. Using these data and subsequent months of the CPS, we find that employment and hours of work of women declined more than for comparable men during the months following the widespread adoption of social distancing measures. The largest relative reductions in employment and hours of work were among women with only school-age children. Women with school-age children suffered losses in employment across the three post-Covid periods ranging from 2.3 to 4.3 percentage points and losses in hours worked ranging from 8.3 to 26.7 percent. This group of women was more integrated into the labor market prior to the arrival of the pandemic because their children were in school enabling them to go to work. The evidence indicates that as their children arrived home due to school closures and distance learning that women's work activity declined disproportionately relative to men.

Estimates based on triple-difference models that compare the experiences of women and men in households with school-age children to similar men and women without children are similar in magnitude to estimates from difference-in-difference models. The similarity of estimates suggests that the majority of the increased gap in male and female labor market outcomes is attributable to increased demands related to children spending more time at home due to school 
closures. When we focus on married couples we find similar results. The relative losses to work activity among women when we focus on married women and men with school-age children further suggests that household labor supply decisions were not favorable to working mothers during the early stages of the pandemic. There appears to have been a sizeable motherhood penalty due to COVID.

In assessing job and personal characteristics that potentially explain the differential experiences between women and men, higher educational attainment and a less-impacted occupational distribution help reduce the unemployment gap observed between women and men. However, other factors unique to the pandemic also play an important role. For example, the ability to telework is much more concentrated among women and helped reduce the observed gap between women and men's unemployment in the Spring when social distancing restrictions were first mandated. Although women's lower concentrations in essential industries widened the unemployment gap in the first two post-Covid periods, as rehiring occurred in Fall 2020, women's unemployment rate in essential industries declined more rapidly than men's.

Three quarters beyond the initiation of the economic downturn and school shutdowns from COVID-19, we observe a general pattern of widening gender gaps due to COVID-19 through the Summer with narrowing gaps in the Fall. The difference-in-difference and triple-difference estimates both show larger negative impacts in the Summer than in the Spring. With the availability of effective vaccinations, it is likely that economic activity will further improve. Estimates from the Fall indicate that the gender gap has narrowed but employment and average hours of men and women both remained below pre-pandemic levels. As the economy re-opens, it remains to be seen if women will fully regain the longer-term progress made in narrowing gender gaps in the labor market prior to the pandemic. 
Beyond these shorter-term considerations, prior research (Juhn and and McCue 2017 and Goldin and Mitchell 2017) demonstrates that women pay a lasting cost in terms of their employment and pay associated with absences from the labor market associated with childbirth. The closure of schools and day care centers due to COVID-19 and the relatively large reductions in employment of women associated with caring for children who returned home could potentially have similar long-term impacts. Lost opportunities for advancement due to absence from work and depreciation of human capital related to the pandemic could lead to long-lasting negative impacts on relative labor market outcomes of women. 


\section{References}

Albanesi, Stefania and Jiyeon Kim. 2021. "Effects of the COVID-19 Recession on the U.S. Labor Market: Occupation, Family, and Gender". Journal of Economic Perspectives 35(3): 3-24.

Alon, Titan M., Matthias Doepke, Jane Olmstead-Rumsey, and Michele Tertilt. The impact of COVID-19 on gender equality. No. w26947. National Bureau of economic research, 2020.

Baker, Marissa G., Trevor K. Peckham, and Noah S. Selxas. 2020. "Estimating the Burden of U.S. Workers Exposed to Infection or Disease: A Key Factor in Containing Risk of COVID-19 Infection”. PLoS ONE 15(4): e0232452.

Bartik, Alexander W., Marianne Bertrand, Feng Lin, Jesse Rothstein, and Matt Unrath. Measuring the labor market at the onset of the COVID-19 crisis. No. w27613. National Bureau of Economic Research, 2020.

Blau, Francine D. and Lawrence M. Kahn. 2013a. "Female Labor Supply: Why is the United States Falling Behind?" American Economic Review Papers and Proceedings, 103(3): 251-256.

Blau, Francine and Lawrence Kahn. 2013b. "The Feasibility and Importance of Adding Measures of Actual Experience to Cross-Sectional Data Collection". Journal of Labor Economics 31(2): S17-S58.

Blinder, Alan S. 1973. "Wage Discrimination: Reduced Form and Structural Variables." Journal of Human Resources 8: 436-455.

Burbio 2021 . "K-12 School Opening Tracker”. https://cai.burbio.com/school-opening-tracker/ Accessed June 21, 2021.

Collins, Caitlyn, Liana Christin Landevar, Leah Ruppanner, and William J. Scarborough. 2020. "COVID-19 and the Gender Gap in Work Hours". Feminist Frontiers DOI: 10.1111/gwao.12506

Couch, Kenneth A., Robert W. Fairlie, and Huanan Xu. "Early evidence of the impacts of COVID-19 on minority unemployment." Journal of Public Economics 192 (2020): 104287.

Deryugina, Tatyana, Olga Shurchkov, and Jenna E. Stearns. 2021. "COVID-19 Disruptions Disproportionately Affect Female Academics,” NBER WP No. 28360.

Dingel, Jonathan I. and Brent Neiman. 2020. "How Many Jobs Can be Done at Home?" Journal of Public Economics, 189: 1-8. 
Fairlie, Robert. 1999. "The Absence of the African-American Owned Business: An Analysis of the Dynamics of Self-Employment."_Journal of Labor Economics, 17(1): 80-108.

Fairlie, Robert W. 2005. "An Extension of the Blinder-Oaxaca Decomposition Technique to Logit and Probit Models," Journal of Economic and Social Measurement, 30(4): 305316.

Goldin, Claudia. 2014. "A Grand Gender Convergence: Its Last Chapter". American Economic Review 104 (4): 1091-1119.

Goldin, Claudia and Joshua Mitchell. 2017. "The New Lifecycle of Women's Employment: Disappearing Humps, Sagging Middles, Expanding Tops". Journal of Economic Perspectives 31 (1): 161-182.

Heggenes, Misty L. 2020. "Why is Mommy So Stressed? Estimating the Immediate Impact of the COVID-19 Shock on Parental Attachment to the Labor Market and the Double Bind of Mothers". Opportunity and Inclusive Growth Institute, Federal Reserve Bank of Minnesota, Institute Working Paper No. 33.

Holder, Michelle, Janelle Jones, and Thomas Masterson. 2021. "The Early Impact of Covid-19 on Job Losses among Black Women in the United States." Feminist Economics, 27(1-2): 103-116.

Jann, B. (2006). "Fairlie: Stata module to generate nonlinear decomposition of binary outcome Differentials." http://ideas.repec.org/c/boc/bocode/s456727.html.

Juhn, Chinhui and Kristin McCue. 2017. "Specialization Then and Now: Marriage, Children, and the Gender Earnings Gap Across Cohorts". Journal of Economic Perspectives 31 (1): 183-204.

Kapteyn, Arie, Marco Angrisani, Dan Bennett, Wändi Bruine de Bruin, Jill Darling, Tania Gutsche, Ying Liu et al. 2020. "Tracking the effect of the COVID-19 pandemic on the lives of American households." Survey Research Methods, 14(2): 179-186.

Montenovo, Laura, Xuan Jiang, Felipe L. Rojas, Ian M. Schmutte, Kosali I. Simon, Bruce A. Weinberg, and Coady Wing. 2020. "Determinants of Disparities in Covid-19 Job Losses". NBER WP 27132.

Oaxaca, Ronald. 1973. "Male-Female Wage Differentials in Urban Labor Markets," International Economic Review, 14: 693-709.

Oaxaca, Ronald, and Michael Ransom. 1994. "On Discrimination and the Decomposition of Wage Differentials," Journal of Econometrics, 61, 5-21.

Waldfogel, Jane. 1998. "Understanding the "Family Gap" in Pay for Women with Children". Journal of Economics Perspectives 12(1): 137.156. 
Zamarro, Gema, and María J. Prados. 2021. "Gender differences in couples' division of childcare, work and mental health during COVID-19." Review of Economics of the Household 1-30.

Zveglich, Joseph E., Yana van der Meulen Rodgers, and Editha A. Lavina. 2019. "Expected Work Experience and the Gender Wage Gap: A New Human Capital Measure". Economic Modelling 83: 372-383. 


\section{Tables and Figures}

Figure 1(a). Employment to Population Ratio, Women vs. Men, January 2017 to December 2020

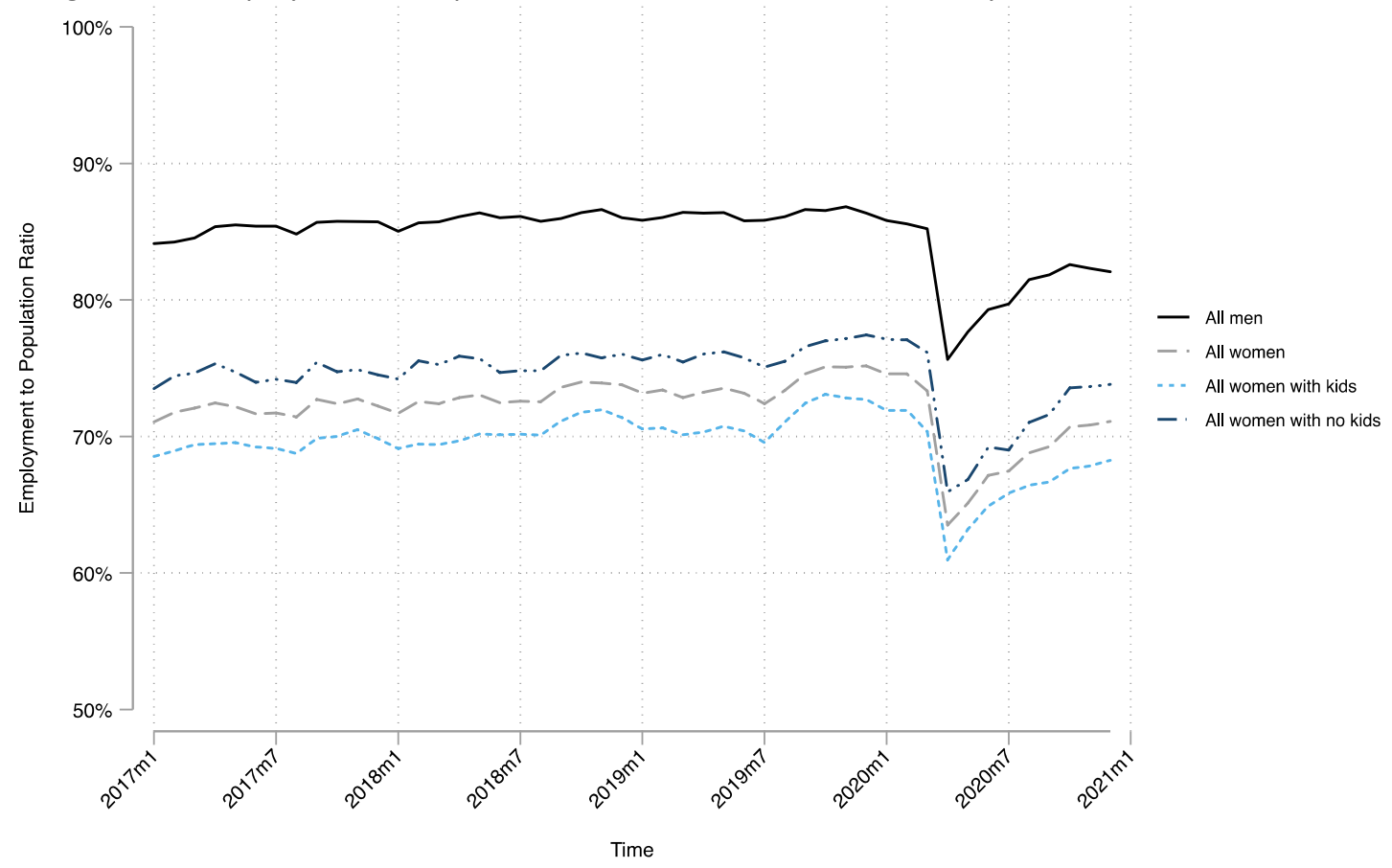

Figure 1(b). Average Hours of Work, Women vs. Men, January 2017 to December 2020

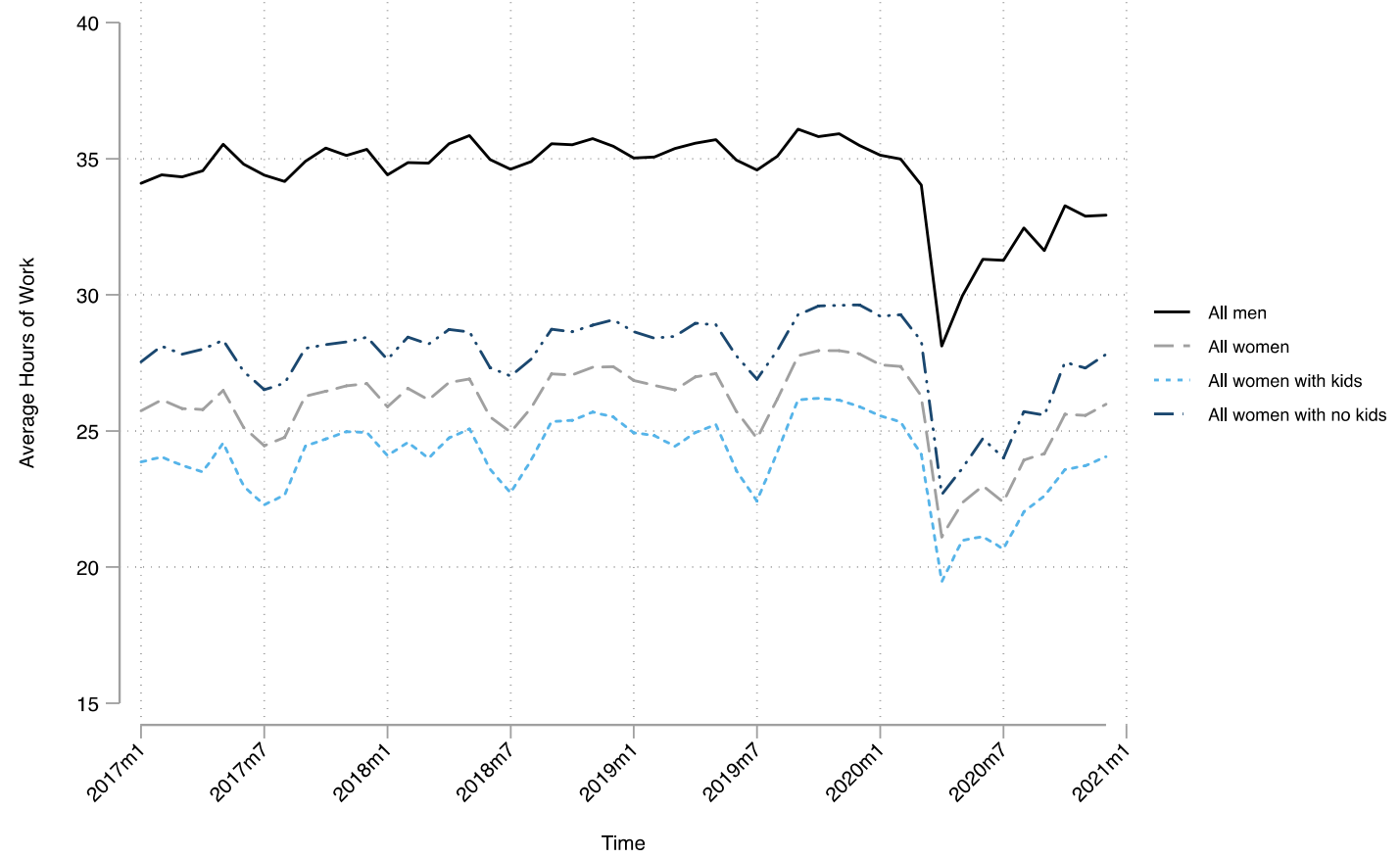


Figure 2(a). Employment to Population Ratio, Women by Children, January 2017 to December 2020

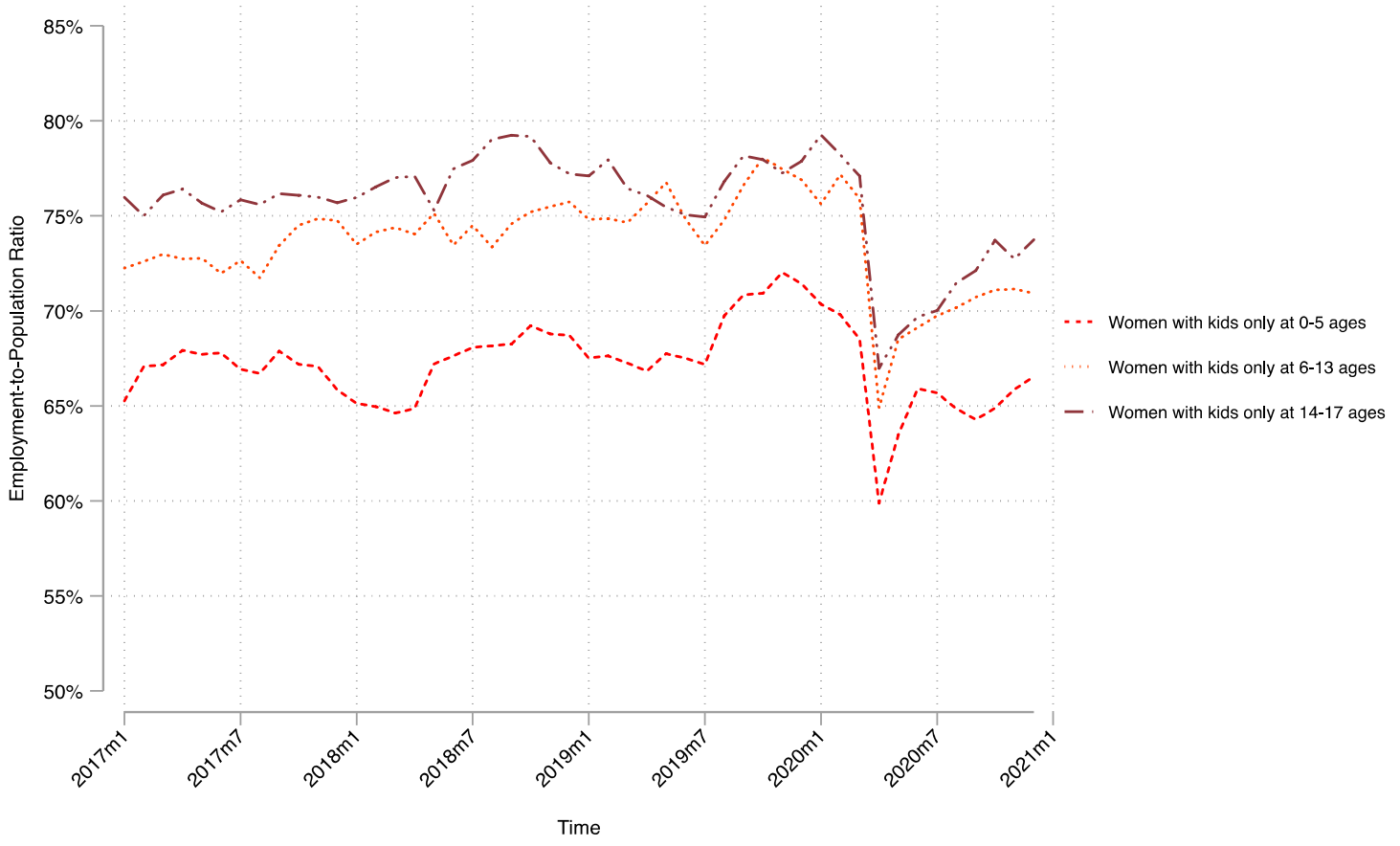

Figure 2(b). Average Hours of Work, Women by Children, January 2017 to December 2020

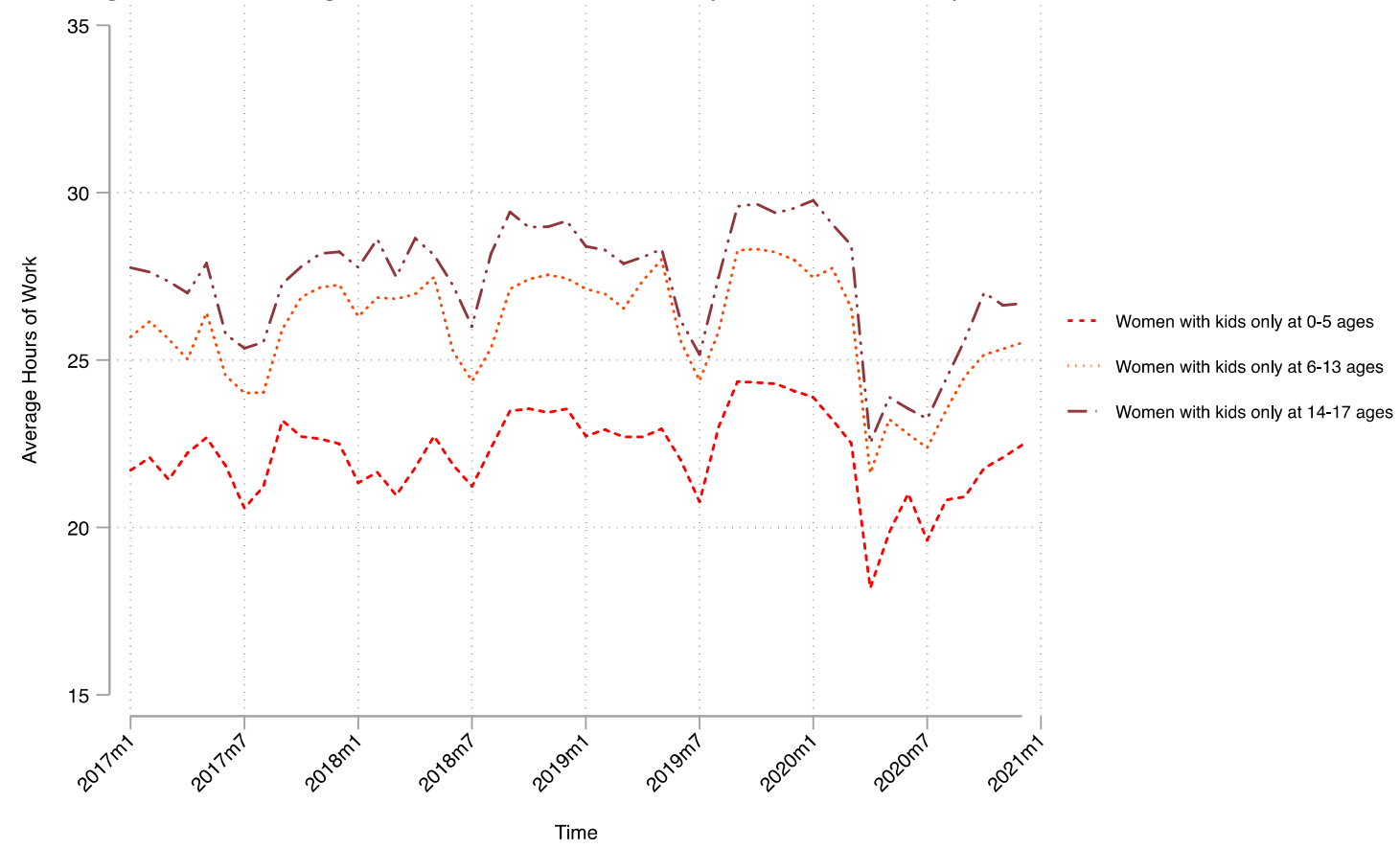


Figure 3. Event Study Coefficients, Employment to Population Ratio, January 2017 to December 2020

(a) No kid

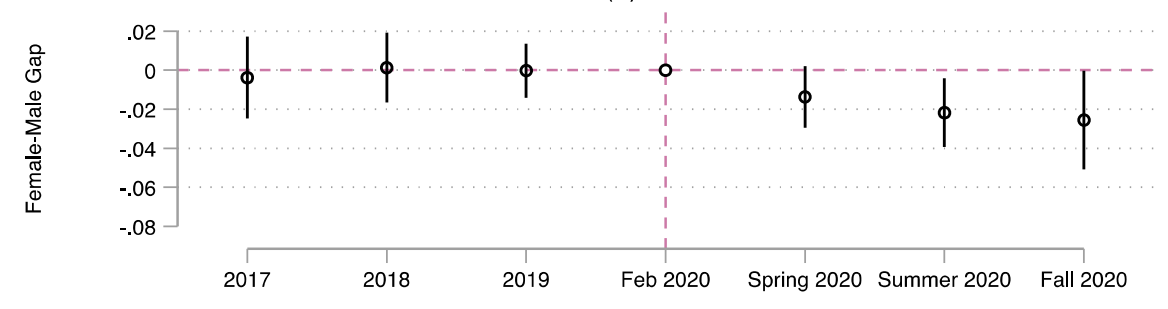

(b) Any 6-17 kid

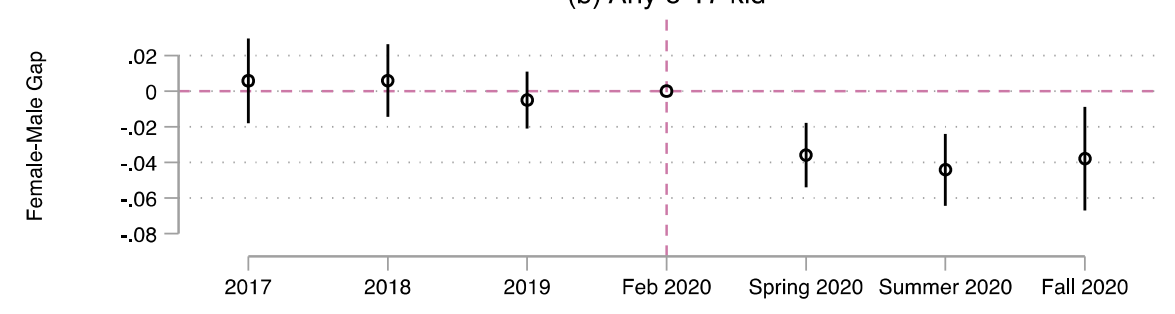

(c) Only 6-17 kid

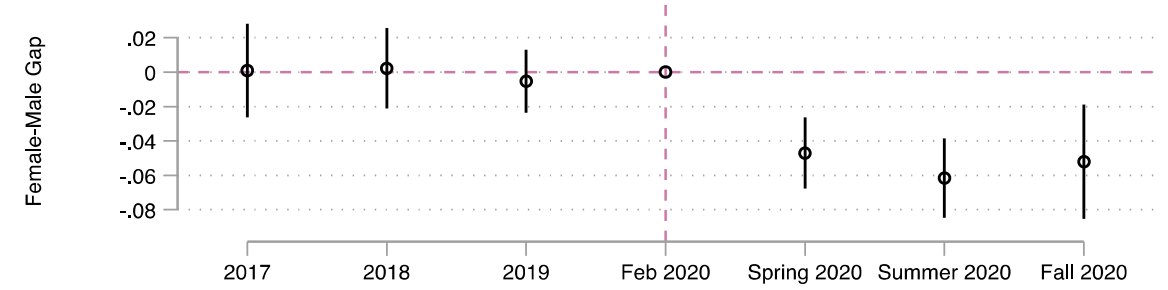

Note: The figures display the results from event-study regressions. Panels (a) to (c) use the same samples as those used in Columns (2), (5), and (7) of Table 3. The sample period covers January 2017 to December 2020. The reference period is February 2020. The post-COVID periods are April through December 2020. Spring includes April and May; Summer includes June to August; Fall includes September to December. Full interactions for January and March 2020, though not reported in the graph, are included in the regressions. All models are estimated using CPS sample weights and robust standard errors. 
Figure 4. Event Study Coefficients, Average Hours of Work, January 2017 to December 2020

(a) No kid

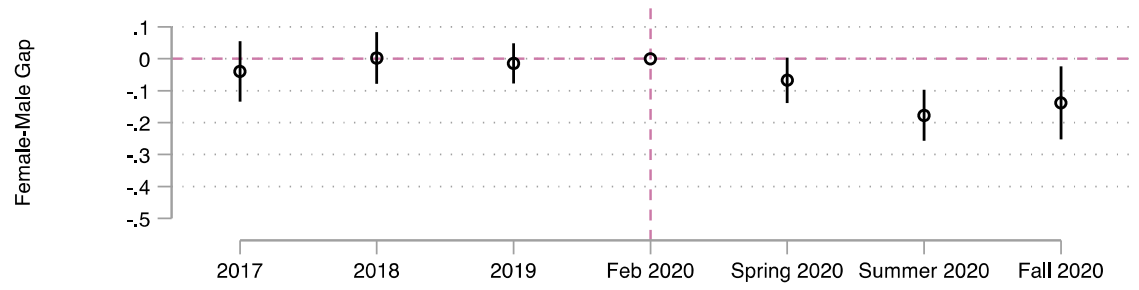

(b) Any 6-17 kid

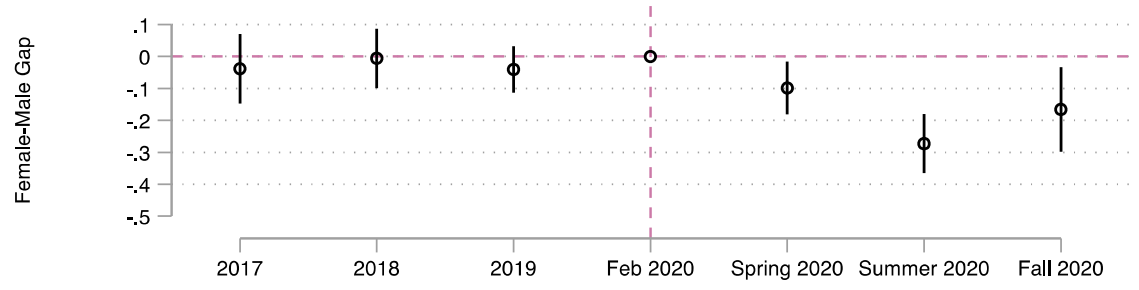

(c) Only 6-17 kid

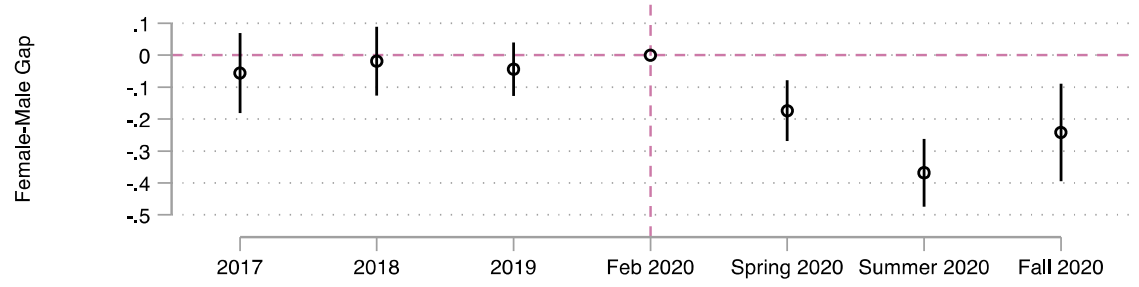

Note: The figures display the results from event-study regressions. Panels (a) to (c) use the same samples as those used in Columns (2), (5), and (7) of Table 3. The sample period covers January 2017 to December 2020. The reference period is February 2020. The post-COVID periods are April through December 2020. Spring includes April and May; Summer includes June to August; Fall includes September to December. Full interactions for January and March 2020, though not reported in the graph, are included in the regressions. All models are estimated using CPS sample weights and robust standard errors. 
Table 1. Employment to Population Ratio

\begin{tabular}{|c|c|c|c|}
\hline & Male & Female & Male-Female Gap \\
\hline \multicolumn{4}{|l|}{ Panel A. All } \\
\hline Jan 2017 - Dec 2019 & 0.858 & 0.729 & 0.129 \\
\hline February 2020 & 0.856 & 0.746 & 0.110 \\
\hline Post-COVID: Spring & 0.767 & 0.643 & 0.124 \\
\hline Post-COVID: Summer & 0.802 & 0.678 & 0.124 \\
\hline Post-COVID: Fall & 0.822 & 0.705 & 0.117 \\
\hline \multicolumn{4}{|c|}{ Panel B. With no children } \\
\hline Jan 2017 - Dec 2019 & 0.816 & 0.754 & 0.062 \\
\hline February 2020 & 0.817 & 0.771 & 0.046 \\
\hline Post-COVID: Spring & 0.716 & 0.664 & 0.052 \\
\hline Post-COVID: Summer & 0.752 & 0.698 & 0.054 \\
\hline Post-COVID: Fall & 0.778 & 0.732 & 0.046 \\
\hline \multicolumn{4}{|l|}{ Panel C. With children } \\
\hline Jan 2017 - Dec 2019 & 0.920 & 0.703 & 0.217 \\
\hline February 2020 & 0.913 & 0.719 & 0.194 \\
\hline Post-COVID: Spring & 0.841 & 0.621 & 0.220 \\
\hline Post-COVID: Summer & 0.876 & 0.657 & 0.219 \\
\hline Post-COVID: Fall & 0.889 & 0.676 & 0.213 \\
\hline \multicolumn{4}{|c|}{ Panel D. With children only at $0-5$ ages } \\
\hline Jan 2017 - Dec 2019 & 0.929 & 0.677 & 0.252 \\
\hline February 2020 & 0.920 & 0.698 & 0.222 \\
\hline Post-COVID: Spring & 0.847 & 0.617 & 0.230 \\
\hline Post-COVID: Summer & 0.876 & 0.655 & 0.221 \\
\hline Post-COVID: Fall & 0.907 & 0.654 & 0.253 \\
\hline \multicolumn{4}{|c|}{ Panel E. With children only at 6-17 ages } \\
\hline Jan 2017 - Dec 2019 & 0.914 & 0.746 & 0.168 \\
\hline February 2020 & 0.907 & 0.763 & 0.144 \\
\hline Post-COVID: Spring & 0.843 & 0.658 & 0.185 \\
\hline Post-COVID: Summer & 0.879 & 0.688 & 0.191 \\
\hline Post-COVID: Fall & 0.886 & 0.715 & 0.171 \\
\hline
\end{tabular}


Table 2. Average Weekly Hours of Work on All Jobs

\begin{tabular}{|c|c|c|c|}
\hline & Male & Female & Male-Female Gap \\
\hline \multicolumn{4}{|l|}{ Panel A. All } \\
\hline Jan 2017 - Dec 2019 & 35.1 & 26.4 & 8.7 \\
\hline February 2020 & 35.0 & 27.4 & 7.6 \\
\hline Post-COVID: Spring & 29.0 & 21.7 & 7.3 \\
\hline Post-COVID: Summer & 31.7 & 23.1 & 8.6 \\
\hline Post-COVID: Fall & 32.7 & 25.3 & 7.3 \\
\hline \multicolumn{4}{|c|}{ Panel B. With no children } \\
\hline Jan 2017 - Dec 2019 & 32.9 & 28.2 & 4.7 \\
\hline February 2020 & 32.9 & 29.3 & 3.6 \\
\hline Post-COVID: Spring & 26.7 & 23.2 & 3.5 \\
\hline Post-COVID: Summer & 29.4 & 24.8 & 4.6 \\
\hline Post-COVID: Fall & 30.4 & 27.1 & 3.3 \\
\hline \multicolumn{4}{|l|}{ Panel C. With children } \\
\hline Jan 2017 - Dec 2019 & 38.3 & 24.5 & 13.8 \\
\hline February 2020 & 38.1 & 25.3 & 12.8 \\
\hline Post-COVID: Spring & 32.5 & 20.2 & 12.3 \\
\hline Post-COVID: Summer & 35.1 & 21.3 & 13.8 \\
\hline Post-COVID: Fall & 36.1 & 23.5 & 12.6 \\
\hline \multicolumn{4}{|c|}{ Panel D. With children only at 0-5 ages } \\
\hline Jan 2017 - Dec 2019 & 38.3 & 22.5 & 15.8 \\
\hline February 2020 & 38.1 & 23.2 & 14.9 \\
\hline Post-COVID: Spring & 32.7 & 19.0 & 13.7 \\
\hline Post-COVID: Summer & 35.1 & 20.5 & 14.6 \\
\hline Post-COVID: Fall & 36.4 & 21.8 & 14.6 \\
\hline \multicolumn{4}{|c|}{ Panel E. With children only at 6-17 ages } \\
\hline Jan 2017 - Dec 2019 & 38.3 & 26.6 & 11.7 \\
\hline February 2020 & 38.1 & 27.6 & 10.5 \\
\hline Post-COVID: Spring & 32.7 & 22.0 & 10.7 \\
\hline Post-COVID: Summer & 35.2 & 22.8 & 12.4 \\
\hline Post-COVID: Fall & 36.3 & 25.5 & 10.8 \\
\hline
\end{tabular}


Table 3. Difference-in-Difference Estimates Relative to Men

\begin{tabular}{|c|c|c|c|c|c|c|c|}
\hline & $(1)$ & $(2)$ & (3) & (4) & (5) & (6) & (7) \\
\hline Sample: & All & No kid & Any kid & $\begin{array}{c}\text { Any } \\
0-5 \text { kid }\end{array}$ & $\begin{array}{c}\text { Any } \\
6-17 \text { kid }\end{array}$ & $\begin{array}{c}\text { Only } \\
0-5 \text { kid }\end{array}$ & $\begin{array}{c}\text { Only } \\
6-17 \text { kid }\end{array}$ \\
\hline \multicolumn{8}{|c|}{ Panel A. Employment to Population Ratio } \\
\hline Post-COVID: Spring * Female & $\begin{array}{c}-0.0094 * \\
(0.0053)\end{array}$ & $\begin{array}{l}-0.0044 \\
(0.0072)\end{array}$ & $\begin{array}{c}-0.0184 * * \\
(0.0075)\end{array}$ & $\begin{array}{c}0.0005 \\
(0.0119)\end{array}$ & $\begin{array}{c}-0.0237 * * * \\
(0.0084)\end{array}$ & $\begin{array}{c}0.0021 \\
(0.0165)\end{array}$ & $\begin{array}{c}-0.0343^{* * *} \\
(0.0096)\end{array}$ \\
\hline Post-COVID: Summer * Female & $\begin{array}{c}-0.0107 * * \\
(0.0048)\end{array}$ & $\begin{array}{l}-0.0064 \\
(0.0065)\end{array}$ & $\begin{array}{c}-0.0189 * * * \\
(0.0068)\end{array}$ & $\begin{array}{c}0.0090 \\
(0.0109)\end{array}$ & $\begin{array}{c}-0.0268 * * * \\
(0.0076)\end{array}$ & $\begin{array}{c}0.0102 \\
(0.0151)\end{array}$ & $\begin{array}{c}-0.0425^{* * * *} \\
(0.0086)\end{array}$ \\
\hline Post-COVID: Fall * Female & $\begin{array}{l}-0.0051 \\
(0.0044) \\
\end{array}$ & $\begin{array}{c}0.0001 \\
(0.0059) \\
\end{array}$ & $\begin{array}{c}-0.0143^{* *} \\
(0.0063)\end{array}$ & $\begin{array}{l}-0.0055 \\
(0.0100) \\
\end{array}$ & $\begin{array}{l}-0.0123^{*} \\
(0.0070) \\
\end{array}$ & $\begin{array}{l}-0.0223 \\
(0.0139) \\
\end{array}$ & $\begin{array}{c}-0.0226 * * * \\
(0.0080)\end{array}$ \\
\hline \multicolumn{8}{|c|}{ Panel B. Unconditional Hours of Work } \\
\hline Post-COVID: Spring * Female & $\begin{array}{c}-0.0108 \\
(0.0236)\end{array}$ & $\begin{array}{l}-0.0105 \\
(0.0323)\end{array}$ & $\begin{array}{c}-0.0219 \\
(0.0339)\end{array}$ & $\begin{array}{c}0.0811 \\
(0.0530)\end{array}$ & $\begin{array}{c}-0.0371 \\
(0.0381)\end{array}$ & $\begin{array}{c}0.0463 \\
(0.0744)\end{array}$ & $\begin{array}{c}-0.1051^{* *} \\
(0.0436)\end{array}$ \\
\hline Post-COVID: Summer * Female & $\begin{array}{c}-0.1108 * * * \\
(0.0216)\end{array}$ & $\begin{array}{c}-0.0870 * * * \\
(0.0295)\end{array}$ & $\begin{array}{c}-0.1434^{* * *} \\
(0.0310)\end{array}$ & $\begin{array}{c}0.0059 \\
(0.0488)\end{array}$ & $\begin{array}{c}-0.1831^{* * *} \\
(0.0346)\end{array}$ & $\begin{array}{c}0.0083 \\
(0.0688)\end{array}$ & $\begin{array}{c}-0.2668 * * * \\
(0.0396)\end{array}$ \\
\hline Post-COVID: Fall * Female & $\begin{array}{l}-0.0018 \\
(0.0197)\end{array}$ & $\begin{array}{c}0.0087 \\
(0.0268)\end{array}$ & $\begin{array}{l}-0.0277 \\
(0.0282)\end{array}$ & $\begin{array}{c}0.0351 \\
(0.0444)\end{array}$ & $\begin{array}{l}-0.0286 \\
(0.0315)\end{array}$ & $\begin{array}{l}-0.0285 \\
(0.0631)\end{array}$ & $\begin{array}{c}-0.0834 * * \\
(0.0361)\end{array}$ \\
\hline Personal & Yes & Yes & Yes & Yes & Yes & Yes & Yes \\
\hline Seasonality & Yes & Yes & Yes & Yes & Yes & Yes & Yes \\
\hline Time Trend & Yes & Yes & Yes & Yes & Yes & Yes & Yes \\
\hline Year FE & Yes & Yes & Yes & Yes & Yes & Yes & Yes \\
\hline State FE & Yes & Yes & Yes & Yes & Yes & Yes & Yes \\
\hline Sample Size & $2,228,185$ & $1,225,424$ & $1,002,761$ & 426,973 & 789,126 & 213,635 & 575,788 \\
\hline
\end{tabular}

Notes: The sample consists of all people ages 25 to 55. The dependent variable is the Employment to Population ratio in Panel A and is log weekly working hours on all jobs in Panel B (including zero hours for those not working and top-coded to 60 hours). Log hours are transformed with inverse hyperbolic sine to approximate logs and include zero hours. The sample period covers January 2017 to December 2020. The reference period is February 2020. Post-COVID periods include April to May 2020 for Spring, June to August 2020 for Summer, and September to December 2020 for Fall. Full interactions for March 2020 and the pre-COVID period, though not reported in the table, are included in the analysis. All specifications include full interaction terms and a constant term. All specifications also control for years of potential work experience and its square, education level, and marital status. Specifications are estimated using CPS sample weights and robust standard errors. Standard errors in parentheses. ${ }^{*} p<0.10,{ }^{* *} p<0.05,{ }^{* * *} p<0.01$ 
Table 4. Triple-Difference Estimates of Changes Due to Presence of Children

\begin{tabular}{|c|c|c|c|c|c|}
\hline \multirow[b]{2}{*}{ Sample: } & (1) & $(2)$ & (3) & (4) & (5) \\
\hline & $\begin{array}{l}\text { Any kid } \\
+ \text { no kid }\end{array}$ & $\begin{array}{l}\text { Any 0-5 kid } \\
+ \text { no kid }\end{array}$ & $\begin{array}{l}\text { Any 6-17 kid } \\
+ \text { no kid }\end{array}$ & $\begin{array}{l}\text { Only 0-5 kid } \\
+ \text { no kid }\end{array}$ & $\begin{array}{l}\text { Only 6-17 kid } \\
+ \text { no kid }\end{array}$ \\
\hline \multicolumn{6}{|l|}{ Panel A. Employment to Population Ratio } \\
\hline \multirow[t]{2}{*}{ Post-COVID: Spring * Female * Child } & $-0.0235^{* *}$ & -0.0083 & $-0.0268 * *$ & -0.0086 & $-0.0369 * * *$ \\
\hline & $(0.0105)$ & $(0.0142)$ & $(0.0113)$ & $(0.0185)$ & $(0.0123)$ \\
\hline \multirow[t]{2}{*}{ Post-COVID: Summer * Female * Child } & $-0.0219 * *$ & 0.0024 & $-0.0280 * * *$ & 0.0016 & $-0.0429 * * *$ \\
\hline & $(0.0095)$ & $(0.0129)$ & $(0.0102)$ & $(0.0170)$ & $(0.0112)$ \\
\hline \multirow[t]{2}{*}{ Post-COVID: Fall * Female * Child } & $-0.0230 * * *$ & -0.0177 & $-0.0190 * *$ & $-0.0361 * *$ & $-0.0279 * * *$ \\
\hline & $(0.0087)$ & $(0.0118)$ & $(0.0093)$ & $(0.0156)$ & $(0.0103)$ \\
\hline \multicolumn{6}{|l|}{ Panel B. Unconditional Hours of Work } \\
\hline \multirow[t]{2}{*}{ Post-COVID: Spring * Female * Child } & -0.0708 & 0.0167 & -0.0723 & -0.0329 & $-0.1387 * *$ \\
\hline & $(0.0476)$ & $(0.0638)$ & $(0.0510)$ & $(0.0842)$ & $(0.0561)$ \\
\hline \multirow[t]{2}{*}{ Post-COVID: Summer * Female * Child } & $-0.1164 * * *$ & 0.0174 & $-0.1432 * * *$ & 0.0058 & $-0.2232 * * *$ \\
\hline & $(0.0435)$ & $(0.0588)$ & $(0.0466)$ & $(0.0782)$ & $(0.0513)$ \\
\hline \multirow[t]{2}{*}{ Post-COVID: Fall * Female * Child } & $-0.0922 * *$ & -0.0444 & $-0.0793 *$ & $-0.1192 *$ & $-0.1276 * * *$ \\
\hline & $(0.0394)$ & $(0.0534)$ & $(0.0423)$ & $(0.0717)$ & $(0.0467)$ \\
\hline Personal & Yes & Yes & Yes & Yes & Yes \\
\hline Seasonality & Yes & Yes & Yes & Yes & Yes \\
\hline Time Trend & Yes & Yes & Yes & Yes & Yes \\
\hline Year FE & Yes & Yes & Yes & Yes & Yes \\
\hline State FE & Yes & Yes & Yes & Yes & Yes \\
\hline Sample Size & $2,228,185$ & $1,652,397$ & $2,014,550$ & $1,439,059$ & $1,801,212$ \\
\hline \multicolumn{6}{|c|}{$\begin{array}{l}\text { Notes: The sample consists of all people ages } 25 \text { to } 55 \text {. The dependent variable is the Employment to Population ratio in Panel A and is log weekly working } \\
\text { hours on all jobs in Panel B (including zero hours for those not working and top-coded to } 60 \text { hours). Log hours are transformed with inverse hyperbolic } \\
\text { sine to approximate logs and include zero hours. The sample period covers January } 2017 \text { to December } 2020 \text {. The reference period is February } 2020 \text {. Post- } \\
\text { COVID periods include April to May } 2020 \text { for Spring, June to August } 2020 \text { for Summer, and September to December } 2020 \text { for Fall. Full interactions for } \\
\text { March } 2020 \text { and the pre-COVID period, though not reported in the table, are included in the analysis. All specifications include full interaction terms of } \\
\text { the triple interaction and a constant term. The child indicator equals to } 1 \text { for the presence of children of different ages and equals to } 0 \text { for no presence } \\
\text { of children. All specifications also control for years of potential work experience and its square, education level, and marital status. Specifications are } \\
\text { estimated using CPS sample weights and robust standard errors. Standard errors in parentheses. }{ }^{*} p<0.10,{ }^{* *} p<0.05,{ }^{* * *}<<0.01\end{array}$} \\
\hline
\end{tabular}


Table 5. Worker and Job Characteristics and Unemployment from COVID-19

\begin{tabular}{|c|c|c|c|c|}
\hline & \multicolumn{3}{|c|}{ Percentage (Feb. 2017 - Feb. 2020) } & \multirow{2}{*}{$\begin{array}{l}\text { April } 2020 \text { to December } 2020 \\
\text { National Unemployment Rate }\end{array}$} \\
\hline & Men & Women & Total & \\
\hline \multicolumn{5}{|l|}{ Essential } \\
\hline Nonessential industry & $11.8 \%$ & $17.1 \%$ & $14.2 \%$ & $16.0 \%$ \\
\hline Essential industry & $88.3 \%$ & $82.9 \%$ & $85.8 \%$ & $7.2 \%$ \\
\hline \multicolumn{5}{|l|}{ Education } \\
\hline High school dropout & $8.8 \%$ & $5.6 \%$ & $7.3 \%$ & $13.5 \%$ \\
\hline High school graduate & $28.1 \%$ & $21.2 \%$ & $24.9 \%$ & $11.2 \%$ \\
\hline Some college & $25.5 \%$ & $27.8 \%$ & $26.6 \%$ & $9.3 \%$ \\
\hline College graduate & $24.7 \%$ & $28.2 \%$ & $26.3 \%$ & $6.4 \%$ \\
\hline Graduate school & $13.0 \%$ & $17.3 \%$ & $15.0 \%$ & $3.9 \%$ \\
\hline \multicolumn{5}{|l|}{ Region } \\
\hline Northeast & $17.1 \%$ & $17.7 \%$ & $17.3 \%$ & $9.7 \%$ \\
\hline Midwest & $20.7 \%$ & $21.3 \%$ & $21.0 \%$ & $7.5 \%$ \\
\hline South & $37.3 \%$ & $37.5 \%$ & $37.4 \%$ & $7.4 \%$ \\
\hline West & $25.0 \%$ & $23.6 \%$ & $24.3 \%$ & $9.4 \%$ \\
\hline \multicolumn{5}{|l|}{ Experience } \\
\hline Potential experience (years) & 20.4 & 20.0 & 20.2 & \\
\hline Less than median & & & & $8.6 \%$ \\
\hline More than median & & & & $8.1 \%$ \\
\hline \multicolumn{5}{|l|}{ Major industry } \\
\hline Agriculture, forestry, fishing, and hunting & $1.8 \%$ & $0.8 \%$ & $1.3 \%$ & $6.0 \%$ \\
\hline Mining & $0.9 \%$ & $0.2 \%$ & $0.5 \%$ & $13.2 \%$ \\
\hline Construction & $13.2 \%$ & $1.6 \%$ & $7.8 \%$ & $9.1 \%$ \\
\hline Manufacturing & $13.7 \%$ & $6.6 \%$ & $10.4 \%$ & $7.3 \%$ \\
\hline Wholesale and retail trade & $12.2 \%$ & $11.0 \%$ & $11.7 \%$ & $8.4 \%$ \\
\hline Transportation and utilities & $8.1 \%$ & $3.0 \%$ & $5.7 \%$ & $9.7 \%$ \\
\hline Information & $2.3 \%$ & $1.6 \%$ & $2.0 \%$ & $8.2 \%$ \\
\hline Financial activities & $6.3 \%$ & $8.0 \%$ & $7.1 \%$ & $4.4 \%$ \\
\hline Professional and business services & $14.3 \%$ & $11.7 \%$ & $13.1 \%$ & $6.8 \%$ \\
\hline Educational and health services & $10.7 \%$ & $37.3 \%$ & $23.2 \%$ & $5.9 \%$ \\
\hline Leisure and hospitality & $7.2 \%$ & $8.2 \%$ & $7.7 \%$ & $24.1 \%$ \\
\hline Other services & $4.1 \%$ & $5.3 \%$ & $4.7 \%$ & $11.7 \%$ \\
\hline Public administration & $5.2 \%$ & $4.7 \%$ & $5.0 \%$ & $2.6 \%$ \\
\hline \multicolumn{5}{|l|}{ Major occupation } \\
\hline Management, business, and financial occupations & $17.9 \%$ & $17.2 \%$ & $17.6 \%$ & $4.5 \%$ \\
\hline Professional and related occupations & $20.1 \%$ & $30.8 \%$ & $25.1 \%$ & $5.0 \%$ \\
\hline Service occupations & $12.8 \%$ & $19.3 \%$ & $15.9 \%$ & $14.9 \%$ \\
\hline Sales and related occupations & $8.8 \%$ & $9.1 \%$ & $8.9 \%$ & $9.0 \%$ \\
\hline Office and administrative support occupations & $5.7 \%$ & $16.5 \%$ & $10.8 \%$ & $7.8 \%$ \\
\hline Farming, fishing, and forestry occupations & $1.0 \%$ & $0.4 \%$ & $0.7 \%$ & $10.2 \%$ \\
\hline Construction and extraction occupations & $10.7 \%$ & $0.4 \%$ & $5.9 \%$ & $11.0 \%$ \\
\hline Installation, maintenance, and repair occupations & $5.9 \%$ & $0.3 \%$ & $3.3 \%$ & $7.5 \%$ \\
\hline Production occupations & $7.5 \%$ & $3.4 \%$ & $5.6 \%$ & $10.0 \%$ \\
\hline Transportation and material moving occupations & $9.4 \%$ & $2.5 \%$ & $6.2 \%$ & $12.6 \%$ \\
\hline \multicolumn{5}{|l|}{ Telework } \\
\hline Share of jobs that can be done at home & $33.1 \%$ & $46.2 \%$ & $39.2 \%$ & \\
\hline Less than median & & & & $10.3 \%$ \\
\hline More than median & & & & $6.3 \%$ \\
\hline \multicolumn{5}{|l|}{ Health risk } \\
\hline Exposed to health risk index (Z-score) & -0.24 & 0.27 & 0.00 & \\
\hline Less than median & & & & $7.2 \%$ \\
\hline More than median & & & & $9.5 \%$ \\
\hline
\end{tabular}

Notes: Sample includes all individuals ages 25 to 55 in the labor force. Risk factor calculations use CPS microdata based on February 2017 to February 2020. The last column shows the April to December national unemployment rate in 2020. 
Table 6. Nonlinear Decompositions of Unemployment

\begin{tabular}{|c|c|c|c|c|}
\hline & $(1)$ & $(2)$ & (3) & (4) \\
\hline & $\begin{array}{c}\text { Pre-COVID } \\
\text { Feb. } 2020 \\
\end{array}$ & $\begin{array}{l}\text { Post-COVID } \\
\text { Spring } 2020\end{array}$ & $\begin{array}{c}\text { Post-COVID } \\
\text { Summer } 2020\end{array}$ & $\begin{array}{c}\text { Post-COVID } \\
\text { Fall } 2020 \\
\end{array}$ \\
\hline Female Unemployment Rate & 2.98 & 12.81 & 9.47 & 6.13 \\
\hline Male Unemployment Rate & 3.75 & 11.21 & 8.32 & 6.15 \\
\hline Female - Male Gap & -0.76 & 1.60 & 1.15 & -0.02 \\
\hline Essential/Major Industry & $\begin{array}{l}-0.15 \\
(0.16)\end{array}$ & $\begin{array}{c}0.95^{* * *} \\
(0.23)\end{array}$ & $\begin{array}{c}0.40 * * \\
(0.16)\end{array}$ & $\begin{array}{c}-0.40 * * * \\
(0.10)\end{array}$ \\
\hline Major Occupation & $\begin{array}{c}-0.57 * * * \\
(0.18)\end{array}$ & $\begin{array}{c}-1.04 * * * \\
(0.25)\end{array}$ & $\begin{array}{c}-0.81 * * * \\
(0.17)\end{array}$ & $\begin{array}{c}-0.58 * * * \\
(0.11)\end{array}$ \\
\hline Education & $\begin{array}{c}-0.24 * * * \\
(0.05)\end{array}$ & $\begin{array}{c}-0.64 * * * \\
(0.07)\end{array}$ & $\begin{array}{c}-0.45 * * * \\
(0.05)\end{array}$ & $\begin{array}{c}-0.27 * * * \\
(0.03)\end{array}$ \\
\hline State & $\begin{array}{c}0.01 \\
(0.02)\end{array}$ & $\begin{array}{l}-0.06^{*} \\
(0.03)\end{array}$ & $\begin{array}{l}-0.04 * \\
(0.02)\end{array}$ & $\begin{array}{l}-0.03^{*} \\
(0.02)\end{array}$ \\
\hline Potential Experience & $\begin{array}{l}0.04 * \\
(0.02)\end{array}$ & $\begin{array}{c}0.07^{* * *} \\
(0.02)\end{array}$ & $\begin{array}{c}0.11 * * * \\
(0.02)\end{array}$ & $\begin{array}{c}0.04 * * * \\
(0.01)\end{array}$ \\
\hline Telework & $\begin{array}{l}-0.07 \\
(0.06)\end{array}$ & $\begin{array}{c}-0.36 * * * \\
(0.09)\end{array}$ & $\begin{array}{l}-0.08 \\
(0.07)\end{array}$ & $\begin{array}{l}-0.07^{*} \\
(0.04)\end{array}$ \\
\hline Health Risk (Z-score) & $\begin{array}{c}0.06 \\
(0.08)\end{array}$ & $\begin{array}{l}-0.23 * \\
(0.12) \\
\end{array}$ & $\begin{array}{l}-0.06 \\
(0.08)\end{array}$ & $\begin{array}{c}0.04 \\
(0.05)\end{array}$ \\
\hline Sample Size & 37,926 & 61,112 & 89,094 & 139,274 \\
\hline
\end{tabular}

Notes: All nonlinear decomposition specifications use pooled coefficient estimates from the full sample of male and female. Sampling weights are used in all specifications. Standard errors are reported in parentheses below contribution estimates. Post-COVID periods include April to May 2020 for Spring, June to August 2020 for Summer, and September to December 2020 for Fall. 


\section{Appendix}

Figure A.1. Male and Female Unemployment Rate in Essential Industries

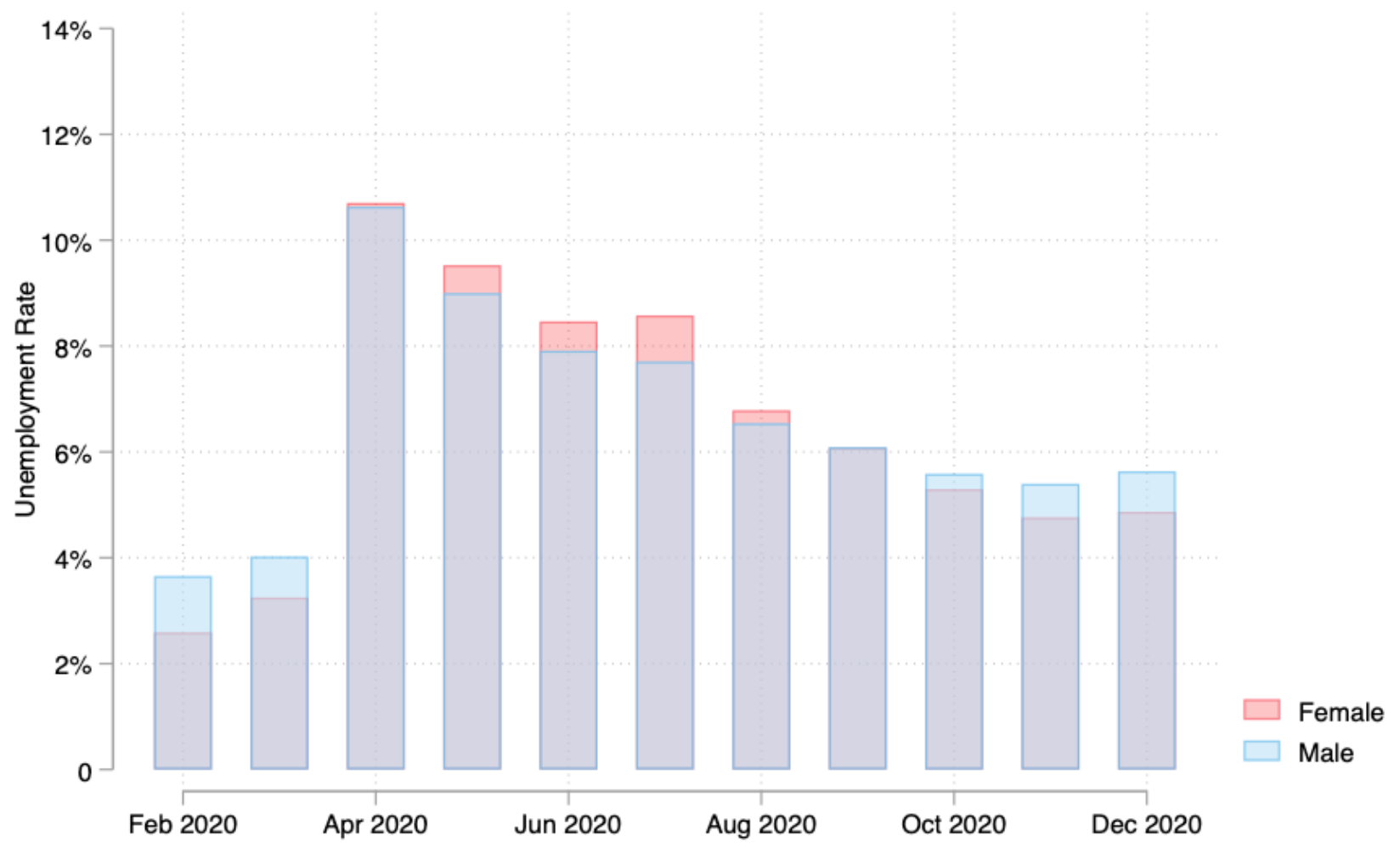

Notes: Figure plots unemployment rates of men and women ages 25 to 55 in essential industries, from February 2020 to December 2020. All calculations use CPS sample weights. 
Figure A.2. Male and Female Share in the Labor Force by Industry
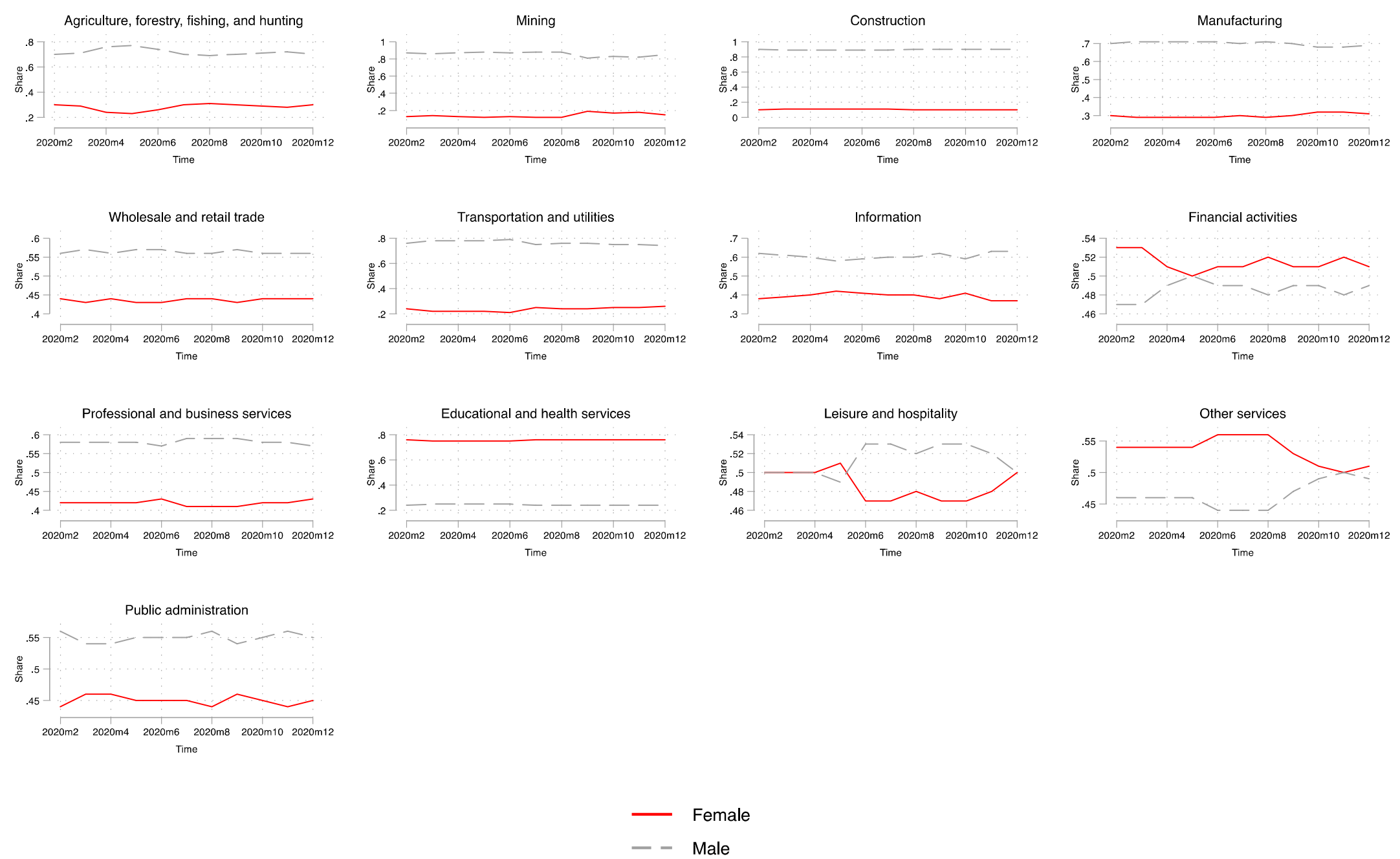

Notes: Figure plots the share of men and women ages 25 to 55 in the labor force by industry, from February 2020 to December 2020. All calculations use CPS sample weights. 
Table A.1. Difference-in-Difference Estimates by Month

\begin{tabular}{|c|c|c|c|c|c|c|c|}
\hline \multirow[b]{2}{*}{ Sample: } & $(1)$ & $(2)$ & (3) & (4) & $(5)$ & (6) & (7) \\
\hline & All & No kid & Any kid & $\begin{array}{c}\text { Any } \\
0-5 \text { kid }\end{array}$ & $\begin{array}{c}\text { Any } \\
6-17 \text { kid }\end{array}$ & $\begin{array}{c}\text { Only } \\
0-5 \text { kid }\end{array}$ & $\begin{array}{c}\text { Only } \\
6-17 \text { kid }\end{array}$ \\
\hline \multicolumn{8}{|c|}{ Panel A. Employment to Population Ratio } \\
\hline \multirow[t]{2}{*}{ April * Female } & -0.0067 & 0.0005 & $-0.0161 *$ & 0.0057 & $-0.0177^{*}$ & -0.0085 & $-0.0332 * * *$ \\
\hline & $(0.0064)$ & $(0.0088)$ & $(0.0092)$ & $(0.0144)$ & $(0.0103)$ & $(0.0200)$ & $(0.0118)$ \\
\hline \multirow[t]{2}{*}{ May * Female } & $-0.0120 *$ & -0.0092 & $-0.0206 * *$ & -0.0047 & $-0.0297 * * *$ & 0.0130 & $-0.0353 * * *$ \\
\hline & $(0.0065)$ & (0.0089) & $(0.0091)$ & $(0.0145)$ & $(0.0103)$ & $(0.0201)$ & $(0.0116)$ \\
\hline \multirow[t]{2}{*}{ June * Female } & -0.0086 & -0.0018 & $-0.0209 * *$ & 0.0056 & $-0.0307 * * *$ & 0.0153 & $-0.0440 * * *$ \\
\hline & $(0.0065)$ & (0.0089) & $(0.0092)$ & $(0.0146)$ & (0.0104) & (0.0199) & $(0.0117)$ \\
\hline \multirow[t]{2}{*}{ July * Female } & -0.0097 & -0.0087 & -0.0142 & 0.017 & $-0.0245^{* *}$ & 0.0223 & $-0.0404 * * *$ \\
\hline & $(0.0065)$ & (0.0089) & $(0.0091)$ & (0.0145) & $(0.0102)$ & $(0.0202)$ & $(0.0115)$ \\
\hline \multirow[t]{2}{*}{ August * Female } & $-0.0138 * *$ & -0.0089 & $-0.0213 * *$ & 0.0044 & $-0.0250 * *$ & -0.0072 & $-0.0428 * * *$ \\
\hline & $(0.0063)$ & $(0.0086)$ & $(0.0089)$ & (0.0141) & $(0.0099)$ & (0.0197) & $(0.0113)$ \\
\hline \multirow[t]{2}{*}{ September * Female } & $-0.0132 * *$ & -0.0088 & $-0.0220 * * *$ & -0.0086 & $-0.0229 * *$ & -0.0195 & $-0.0339 * * *$ \\
\hline & (0.0059) & $(0.0081)$ & $(0.0084)$ & (0.0133) & $(0.0094)$ & (0.0187) & $(0.0108)$ \\
\hline \multirow[t]{2}{*}{ October * Female } & -0.0064 & -0.0036 & -0.0111 & -0.0091 & -0.0082 & -0.0230 & -0.0138 \\
\hline & $(0.0058)$ & (0.0079) & $(0.0083)$ & (0.0131) & (0.0093) & (0.0184) & (0.0107) \\
\hline \multirow[t]{2}{*}{ November * Female } & -0.0029 & 0.0052 & $-0.0164 * *$ & -0.0040 & -0.0150 & -0.0228 & $-0.0271 * *$ \\
\hline & $(0.0058)$ & $(0.0080)$ & $(0.0083)$ & (0.0131) & $(0.0093)$ & $(0.0183)$ & $(0.0106)$ \\
\hline \multirow[t]{2}{*}{ December * Female } & 0.0021 & 0.0080 & -0.0077 & -0.0001 & -0.0030 & -0.0247 & -0.0155 \\
\hline & $(0.0059)$ & $(0.0081)$ & $(0.0085)$ & $(0.0134)$ & (0.0095) & $(0.0183)$ & $(0.0108)$ \\
\hline \multicolumn{8}{|c|}{ Panel B. Unconditional Hours of Work } \\
\hline \multirow[t]{2}{*}{ April $*$ Female } & 0.0092 & 0.0189 & -0.0024 & $0.1090 *$ & -0.0059 & 0.0278 & -0.0877 \\
\hline & $(0.0290)$ & (0.0397) & $(0.0417)$ & $(0.0646)$ & $(0.0470)$ & $(0.0903)$ & $(0.0541)$ \\
\hline \multirow[t]{2}{*}{ May * Female } & -0.0306 & -0.0394 & -0.0414 & 0.0534 & -0.0685 & 0.0654 & $-0.1228 * *$ \\
\hline & $(0.0291)$ & (0.0397) & $(0.0415)$ & $(0.0650)$ & $(0.0466)$ & $(0.0906)$ & $(0.0534)$ \\
\hline \multirow[t]{2}{*}{ June * Female } & $-0.0937 * * *$ & -0.0519 & $-0.1570 * * *$ & 0.0088 & $-0.2157 * * *$ & 0.0655 & $-0.2939 * * *$ \\
\hline & $(0.0294)$ & $(0.0402)$ & $(0.0419)$ & $(0.0660)$ & $(0.0471)$ & (0.0913) & $(0.0537)$ \\
\hline \multirow[t]{2}{*}{ July * Female } & $-0.1433 * * *$ & $-0.1314 * * *$ & $-0.1568 * * *$ & -0.0205 & $-0.1943 * * *$ & -0.0193 & $-0.2708 * * *$ \\
\hline & $(0.0295)$ & (0.0404) & $(0.0421)$ & $(0.0663)$ & $(0.0470)$ & $(0.0935)$ & $(0.0539)$ \\
\hline \multirow[t]{2}{*}{ August * Female } & $-0.0950 * * *$ & $-0.0779 * *$ & $-0.1158 * * *$ & 0.0300 & $-0.1386 * * *$ & -0.023 & $-0.2349 * * *$ \\
\hline & -0.0285 & -0.0389 & -0.0407 & (0.0639) & $(0.0456)$ & (0.0901) & $(0.0523)$ \\
\hline \multirow[t]{2}{*}{ September * Female } & -0.0276 & -0.0327 & -0.0398 & 0.0407 & -0.0628 & 0.0396 & $-0.1103^{* *}$ \\
\hline & $(0.0265)$ & $(0.0362)$ & (0.0379) & (0.0594) & $(0.0423)$ & $(0.0845)$ & $(0.0487)$ \\
\hline \multirow[t]{2}{*}{ October * Female } & -0.0200 & -0.0181 & -0.0270 & -0.0005 & -0.0212 & -0.0509 & -0.0529 \\
\hline & $(0.0262)$ & (0.0355) & $(0.0376)$ & $(0.0586)$ & $(0.0421)$ & $(0.0836)$ & $(0.0486)$ \\
\hline November * Female & 0.0081 & 0.0280 & -0.0330 & 0.0558 & -0.0349 & -0.0347 & $-0.1073^{* *}$ \\
\hline & $(0.0263)$ & (0.0359) & (0.0375) & $(0.0587)$ & $(0.0420)$ & $(0.0832)$ & $(0.0483)$ \\
\hline December * Female & 0.0336 & 0.0601 & -0.0109 & 0.0441 & 0.0056 & -0.0737 & -0.0623 \\
\hline & $(0.0269)$ & $(0.0367)$ & $(0.0383)$ & $(0.0601)$ & $(0.0431)$ & $(0.0841)$ & $(0.0492)$ \\
\hline Personal & Yes & Yes & Yes & Yes & Yes & Yes & Yes \\
\hline Seasonality & Yes & Yes & Yes & Yes & Yes & Yes & Yes \\
\hline Time Trend & Yes & Yes & Yes & Yes & Yes & Yes & Yes \\
\hline Year FE & Yes & Yes & Yes & Yes & Yes & Yes & Yes \\
\hline State FE & Yes & Yes & Yes & Yes & Yes & Yes & Yes \\
\hline Sample Size & $2,228,185$ & $1,225,424$ & $1,002,761$ & 426,973 & 789,126 & 213,635 & 575,788 \\
\hline
\end{tabular}

Notes: The sample consists of all people ages 25 to 55. The dependent variable is the Employment to Population ratio in Panel A and is log weekly working hours on all jobs in Panel B (including zero hours for those not working and top-coded to 60 hours). Log hours are transformed with inverse hyperbolic sine to approximate logs and include zero hours. The sample period covers January 2017 to December 2020 . The reference period is February 2020 . Full interactions for March 2020 and the pre-COVID period, though not reported in the table, are included in the analysis. All specifications include full interaction terms and a constant term. All specifications also control for years of potential work experience and its square, education level, and marital status. Specifications are estimated using CPS sample weights and robust standard errors. Standard errors in parentheses. ${ }^{*} p<0.10, * * p<0.05, * * * p<0.01$ 
Table A.2. Triple-Difference Estimates by Month

\begin{tabular}{|c|c|c|c|c|c|}
\hline & (1) & $(2)$ & (3) & (4) & (5) \\
\hline Sample: & $\begin{array}{l}\text { Any kid } \\
+ \text { no kid }\end{array}$ & $\begin{array}{l}\text { Any 0-5 kid } \\
+ \text { no kid }\end{array}$ & $\begin{array}{c}\text { Any 6-17 kid } \\
+ \text { no kid }\end{array}$ & $\begin{array}{l}\text { Only 0-5 kid } \\
+ \text { no kid }\end{array}$ & $\begin{array}{c}\text { Only 6-17 kid } \\
+ \text { no kid }\end{array}$ \\
\hline \multicolumn{6}{|c|}{ Panel A. Employment to Population Ratio } \\
\hline April * Female * Child & $\begin{array}{c}-0.0260^{* *} \\
(0.0128)\end{array}$ & $\begin{array}{l}-0.0077 \\
(0.0171)\end{array}$ & $\begin{array}{l}-0.0258^{*} \\
(0.0138)\end{array}$ & $\begin{array}{l}-0.0233 \\
(0.0222)\end{array}$ & $\begin{array}{c}-0.0409 * * * \\
(0.0150)\end{array}$ \\
\hline May $*$ Female $*$ Child & $\begin{array}{c}-0.0211 \\
(0.0128)\end{array}$ & $\begin{array}{l}-0.0091 \\
(0.0172)\end{array}$ & $\begin{array}{c}-0.0281^{* *} \\
(0.0137)\end{array}$ & $\begin{array}{c}0.0066 \\
(0.0224)\end{array}$ & $\begin{array}{c}-0.0331^{* *} \\
(0.0149)\end{array}$ \\
\hline June * Female * Child & $\begin{array}{c}-0.0287^{* *} \\
(0.0129)\end{array}$ & $\begin{array}{l}-0.0061 \\
(0.0173)\end{array}$ & $\begin{array}{c}-0.0366^{* * *} \\
(0.0138)\end{array}$ & $\begin{array}{c}0.0019 \\
(0.0222)\end{array}$ & $\begin{array}{c}-0.0492 * * * \\
(0.0150)\end{array}$ \\
\hline July * Female $*$ Child & $\begin{array}{l}-0.0153 \\
(0.0128)\end{array}$ & $\begin{array}{c}0.0123 \\
(0.0173)\end{array}$ & $\begin{array}{c}-0.0238^{*} \\
(0.0137)\end{array}$ & $\begin{array}{c}0.0156 \\
(0.0225)\end{array}$ & $\begin{array}{c}-0.0387^{* * *} \\
(0.0148)\end{array}$ \\
\hline August $*$ Female $*$ Child & $\begin{array}{l}-0.0216 * \\
(0.0124)\end{array}$ & $\begin{array}{c}0.0009 \\
(0.0167)\end{array}$ & $\begin{array}{c}-0.0237^{*} \\
(0.0133)\end{array}$ & $\begin{array}{l}-0.0127 \\
(0.0219)\end{array}$ & $\begin{array}{c}-0.0407 * * * \\
(0.0145)\end{array}$ \\
\hline September * Female * Child & $\begin{array}{l}-0.0220 * \\
(0.0117)\end{array}$ & $\begin{array}{l}-0.0121 \\
(0.0158)\end{array}$ & $\begin{array}{l}-0.0212 * \\
(0.0126)\end{array}$ & $\begin{array}{l}-0.0240 \\
(0.0207)\end{array}$ & $\begin{array}{c}-0.0310^{* *} \\
(0.0137)\end{array}$ \\
\hline October * Female * Child & $\begin{array}{l}-0.0161 \\
(0.0115)\end{array}$ & $\begin{array}{l}-0.0177 \\
(0.0155)\end{array}$ & $\begin{array}{l}-0.0111 \\
(0.0123)\end{array}$ & $\begin{array}{l}-0.0330 \\
(0.0204)\end{array}$ & $\begin{array}{l}-0.0153 \\
(0.0135)\end{array}$ \\
\hline November $*$ Female $*$ Child & $\begin{array}{c}-0.0304 * * * \\
(0.0115)\end{array}$ & $\begin{array}{l}-0.0216 \\
(0.0155)\end{array}$ & $\begin{array}{c}-0.0268 * * \\
(0.0124)\end{array}$ & $\begin{array}{c}-0.0424 * * \\
(0.0203)\end{array}$ & $\begin{array}{c}-0.0375 * * * \\
(0.0135)\end{array}$ \\
\hline December * Female * Child & $\begin{array}{c}-0.0241 * * \\
(0.0117) \\
\end{array}$ & $\begin{array}{l}-0.0199 \\
(0.0158) \\
\end{array}$ & $\begin{array}{l}-0.0173 \\
(0.0126) \\
\end{array}$ & $\begin{array}{c}-0.0458^{* *} \\
(0.0204) \\
\end{array}$ & $\begin{array}{c}-0.0284^{* *} \\
(0.0137) \\
\end{array}$ \\
\hline \multicolumn{6}{|c|}{ Panel B. Unconditional Hours of Work } \\
\hline April * Female * Child & $\begin{array}{l}-0.0800 \\
(0.0582)\end{array}$ & $\begin{array}{c}0.0178 \\
(0.0772)\end{array}$ & $\begin{array}{l}-0.0705 \\
(0.0624)\end{array}$ & $\begin{array}{l}-0.0767 \\
(0.1011)\end{array}$ & $\begin{array}{c}-0.1515^{* *} \\
(0.0685)\end{array}$ \\
\hline May $*$ Female $*$ Child & $\begin{array}{l}-0.0623 \\
(0.0581)\end{array}$ & $\begin{array}{c}0.0155 \\
(0.0775)\end{array}$ & $\begin{array}{l}-0.0753 \\
(0.0622)\end{array}$ & $\begin{array}{c}0.0124 \\
(0.1015)\end{array}$ & $\begin{array}{l}-0.1273^{*} \\
(0.0680)\end{array}$ \\
\hline June ${ }^{*}$ Female $*$ Child & $\begin{array}{c}-0.1655 * * * \\
(0.0587)\end{array}$ & $\begin{array}{l}-0.0168 \\
(0.0786)\end{array}$ & $\begin{array}{c}-0.2107^{* * *} \\
(0.0629)\end{array}$ & $\begin{array}{c}0.0268 \\
(0.1023)\end{array}$ & $\begin{array}{c}-0.2857^{* * *} \\
(0.0686)\end{array}$ \\
\hline July * Female * Child & $\begin{array}{l}-0.0866 \\
(0.0589)\end{array}$ & $\begin{array}{c}0.0340 \\
(0.0790)\end{array}$ & $\begin{array}{l}-0.1113^{*} \\
(0.0630)\end{array}$ & $\begin{array}{c}0.0210 \\
(0.1044)\end{array}$ & $\begin{array}{c}-0.1832 * * * \\
(0.0689)\end{array}$ \\
\hline August $*$ Female $*$ Child & $\begin{array}{c}-0.0963^{*} \\
-0.0568\end{array}$ & $\begin{array}{c}0.0360 \\
-0.0761\end{array}$ & $\begin{array}{l}-0.1075^{*} \\
-0.0608\end{array}$ & $\begin{array}{l}-0.0300 \\
(0.1006)\end{array}$ & $\begin{array}{c}-0.1999 * * * \\
(0.0667)\end{array}$ \\
\hline September * Female * Child & $\begin{array}{l}-0.0637 \\
(0.0529)\end{array}$ & $\begin{array}{c}0.0021 \\
(0.0708)\end{array}$ & $\begin{array}{l}-0.0747 \\
(0.0565)\end{array}$ & $\begin{array}{l}-0.0075 \\
(0.0944)\end{array}$ & $\begin{array}{l}-0.1165 * \\
(0.0621)\end{array}$ \\
\hline October * Female * Child & $\begin{array}{l}-0.0646 \\
(0.0522)\end{array}$ & $\begin{array}{l}-0.0537 \\
(0.0698)\end{array}$ & $\begin{array}{l}-0.0449 \\
(0.0559)\end{array}$ & $\begin{array}{l}-0.1144 \\
(0.0933)\end{array}$ & $\begin{array}{l}-0.0697 \\
(0.0616)\end{array}$ \\
\hline November ${ }^{*}$ Female $*$ Child & $\begin{array}{c}-0.1173^{* *} \\
(0.0523)\end{array}$ & $\begin{array}{l}-0.0439 \\
(0.0699)\end{array}$ & $\begin{array}{c}-0.1048 * \\
(0.0559)\end{array}$ & $\begin{array}{l}-0.1471 \\
(0.0930)\end{array}$ & $\begin{array}{c}-0.1703^{* * *} \\
(0.0615)\end{array}$ \\
\hline December $*$ Female $*$ Child & $\begin{array}{c}-0.1255^{* *} \\
(0.0533) \\
\end{array}$ & $\begin{array}{l}-0.0844 \\
(0.0715) \\
\end{array}$ & $\begin{array}{l}-0.0954^{*} \\
(0.0572) \\
\end{array}$ & $\begin{array}{c}-0.2118^{* *} \\
(0.0941) \\
\end{array}$ & $\begin{array}{c}-0.1560^{* *} \\
(0.0625) \\
\end{array}$ \\
\hline Personal & Yes & Yes & Yes & Yes & Yes \\
\hline Seasonality & Yes & Yes & Yes & Yes & Yes \\
\hline Time Trend & Yes & Yes & Yes & Yes & Yes \\
\hline Year FE & Yes & Yes & Yes & Yes & Yes \\
\hline State FE & Yes & Yes & Yes & Yes & Yes \\
\hline Sample Size & $2,228,185$ & $1,652,397$ & $2,014,550$ & $1,439,059$ & $1,801,212$ \\
\hline
\end{tabular}


Table A.3. Difference-in-Difference Estimates Relative to Men, Conditional Hours of Work

\begin{tabular}{|c|c|c|c|c|c|c|c|}
\hline \multirow[b]{2}{*}{ Sample: } & $(1)$ & $(2)$ & (3) & $(4)$ & (5) & (6) & (7) \\
\hline & All & No kid & Any kid & $\begin{array}{c}\text { Any } \\
0-5 \text { kid }\end{array}$ & $\begin{array}{c}\text { Any } \\
\text { 6-17 kid }\end{array}$ & $\begin{array}{c}\text { Only } \\
0-5 \text { kid }\end{array}$ & $\begin{array}{c}\text { Only } \\
6-17 \text { kid }\end{array}$ \\
\hline \multirow[t]{2}{*}{ Post-COVID: Spring * Female } & -0.0007 & -0.0076 & 0.0080 & 0.0252 & 0.0061 & 0.0145 & -0.0039 \\
\hline & $(0.0067)$ & $(0.0087)$ & $(0.0102)$ & $(0.0170)$ & $(0.0112)$ & $(0.0241)$ & $(0.0127)$ \\
\hline \multirow[t]{2}{*}{ Post-COVID: Summer * Female } & $-0.0152 * * *$ & $-0.0239 * * *$ & -0.0048 & -0.0017 & -0.0083 & 0.0131 & -0.0054 \\
\hline & $(0.0057)$ & $(0.0075)$ & $(0.0088)$ & $(0.0149)$ & $(0.0098)$ & $(0.0199)$ & $(0.0109)$ \\
\hline \multirow[t]{2}{*}{ Post-COVID: Fall * Female } & $0.0128 * *$ & 0.0038 & $0.0225^{* * *}$ & $0.0429 * * *$ & $0.0147 *$ & $0.0533 * * *$ & 0.0083 \\
\hline & $(0.0051)$ & $(0.0066)$ & $(0.0078)$ & $(0.0134)$ & $(0.0086)$ & $(0.0186)$ & $(0.0095)$ \\
\hline Personal & Yes & Yes & Yes & Yes & Yes & Yes & Yes \\
\hline Seasonality & Yes & Yes & Yes & Yes & Yes & Yes & Yes \\
\hline Time Trend & Yes & Yes & Yes & Yes & Yes & Yes & Yes \\
\hline Year FE & Yes & Yes & Yes & Yes & Yes & Yes & Yes \\
\hline State FE & Yes & Yes & Yes & Yes & Yes & Yes & Yes \\
\hline Sample Size & $1,693,092$ & 924,965 & 768,127 & 314,557 & 606,512 & 161,615 & 453,570 \\
\hline \multicolumn{8}{|c|}{$\begin{array}{l}\text { Notes: The sample consists of all people ages } 25 \text { to } 55 \text {. Conditional hours are based on people who are employed and work positive hours. The sample period } \\
\text { covers January } 2017 \text { to December } 2020 \text {. The reference period is February } 2020 \text {. Post-COVID periods include April to May } 2020 \text { for Spring, June to August } 2020 \\
\text { for Summer, and September to December } 2020 \text { for Fall. Full interactions for March } 2020 \text { and the pre-COVID period, though not reported in the table, are included } \\
\text { in the analysis. All specifications include full interaction terms and a constant term. All specifications also control for years of potential work experience and its } \\
\text { square, education level, and marital status. Specifications are estimated using CPS sample weights and robust standard errors. Standard errors in parentheses. } \\
{ }^{*} p<0.10,{ }^{* *} p<0.05,{ }^{* * *}<0.01\end{array}$} \\
\hline
\end{tabular}


Table A.4. Triple-Difference Estimates of Changes Due to Presence of Children, Conditional Hours of Work

\begin{tabular}{|c|c|c|c|c|c|}
\hline & (1) & $(2)$ & (3) & (4) & (5) \\
\hline Sample: & $\begin{array}{l}\text { Any kid } \\
+ \text { no kid }\end{array}$ & $\begin{array}{l}\text { Any } 0-5 \text { kid } \\
+ \text { no kid }\end{array}$ & $\begin{array}{c}\text { Any 6-17 kid } \\
\text { + no kid }\end{array}$ & $\begin{array}{c}\text { Only 0-5 kid } \\
+ \text { no kid }\end{array}$ & $\begin{array}{c}\text { Only 6-17 kid } \\
+ \text { no kid }\end{array}$ \\
\hline \multirow[t]{2}{*}{ Post-COVID: Spring * Female * Child } & 0.015 & 0.0265 & 0.0140 & 0.0182 & 0.0067 \\
\hline & $(0.0135)$ & $(0.0194)$ & $(0.0143)$ & $(0.0264)$ & $(0.0157)$ \\
\hline \multirow[t]{2}{*}{ Post-COVID: Summer * Female * Child } & $0.0195^{*}$ & 0.0163 & 0.0172 & 0.0339 & $0.0237^{*}$ \\
\hline & $(0.0117)$ & $(0.0170)$ & $(0.0125)$ & $(0.0221)$ & $(0.0135)$ \\
\hline \multirow[t]{2}{*}{ Post-COVID: Fall * Female * Child } & $0.0204 * *$ & $0.0337^{* *}$ & 0.0139 & $0.0470 * *$ & 0.0113 \\
\hline & $(0.0103)$ & $(0.0152)$ & $(0.0110)$ & $(0.0206)$ & $(0.0119)$ \\
\hline Personal & Yes & Yes & Yes & Yes & Yes \\
\hline Seasonality & Yes & Yes & Yes & Yes & Yes \\
\hline Time Trend & Yes & Yes & Yes & Yes & Yes \\
\hline Year FE & Yes & Yes & Yes & Yes & Yes \\
\hline State FE & Yes & Yes & Yes & Yes & Yes \\
\hline Sample Size & $1,693,092$ & $1,239,522$ & $1,531,477$ & $1,086,580$ & $1,378,535$ \\
\hline
\end{tabular}

Notes: The sample consists of all people ages 25 to 55 . Conditional hours are based on people who are employed and work positive hours. The sample period covers January 2017 to December 2020. The reference period is February 2020. Post-COVID periods include April to May 2020 for Spring, June to August 2020 for Summer, and September to December 2020 for Fall. Full interactions for March 2020 and the pre-COVID period, though not reported in the table, are included in the analysis. All specifications include full interaction terms of the triple interaction and a constant term. The child indicator equals to 1 for the presence of children of different ages and equals to 0 for no presence of children. All specifications also control for years of potential work experience and its square, education level, and marital status. Specifications are estimated using CPS sample weights and robust standard errors. Standard errors in parentheses. ${ }^{*} \mathrm{p}<0.10, * * p<0.05, * * * p<0.01$ 
Table A.5. Difference-in-Difference Estimates Relative to Men, Married Sample

\begin{tabular}{|c|c|c|c|c|c|c|c|}
\hline & (1) & $(2)$ & (3) & (4) & (5) & (6) & (7) \\
\hline Sample: & All & No kid & Any kid & $\begin{array}{c}\text { Any } \\
0-5 \text { kid }\end{array}$ & $\begin{array}{c}\text { Any } \\
6-17 \text { kid }\end{array}$ & $\begin{array}{c}\text { Only } \\
0-5 \text { kid }\end{array}$ & $\begin{array}{c}\text { Only } \\
6-17 \text { kid }\end{array}$ \\
\hline \multicolumn{8}{|c|}{ Panel A. Employment to Population Ratio } \\
\hline Post-COVID: Spring * Female & $\begin{array}{c}-0.0093 \\
(0.0066)\end{array}$ & $\begin{array}{l}-0.0039 \\
(0.0106)\end{array}$ & $\begin{array}{l}-0.0134 \\
(0.0084)\end{array}$ & $\begin{array}{c}0.0042 \\
(0.0130)\end{array}$ & $\begin{array}{c}-0.0201 * * \\
(0.0095)\end{array}$ & $\begin{array}{c}0.0107 \\
(0.0181)\end{array}$ & $\begin{array}{c}-0.0280 * * * \\
(0.0108)\end{array}$ \\
\hline Post-COVID: Summer * Female & $\begin{array}{l}-0.0059 \\
(0.0060)\end{array}$ & $\begin{array}{c}0.0056 \\
(0.0096)\end{array}$ & $\begin{array}{c}-0.0139 * \\
(0.0077)\end{array}$ & $\begin{array}{l}0.0216^{*} \\
(0.0120)\end{array}$ & $\begin{array}{c}-0.0238 * * * \\
(0.0087)\end{array}$ & $\begin{array}{c}0.0217 \\
(0.0166)\end{array}$ & $\begin{array}{c}-0.0432^{* * *} \\
(0.0099)\end{array}$ \\
\hline Post-COVID: Fall * Female & $\begin{array}{l}-0.0028 \\
(0.0055) \\
\end{array}$ & $\begin{array}{c}0.0037 \\
(0.0087) \\
\end{array}$ & $\begin{array}{l}-0.0087 \\
(0.0071) \\
\end{array}$ & $\begin{array}{c}0.0017 \\
(0.0111) \\
\end{array}$ & $\begin{array}{l}-0.0059 \\
(0.0080)\end{array}$ & $\begin{array}{l}-0.0189 \\
(0.0155) \\
\end{array}$ & $\begin{array}{c}-0.0182 * * \\
(0.0092) \\
\end{array}$ \\
\hline \multicolumn{8}{|c|}{ Panel B. Unconditional Hours of Work } \\
\hline Post-COVID: Spring * Female & $\begin{array}{c}0.0072 \\
(0.0299)\end{array}$ & $\begin{array}{c}0.0058 \\
(0.0483)\end{array}$ & $\begin{array}{c}0.004 \\
(0.0379)\end{array}$ & $\begin{array}{l}0.1121 * \\
(0.0582)\end{array}$ & $\begin{array}{l}-0.0230 \\
(0.0427)\end{array}$ & $\begin{array}{c}0.1057 \\
(0.0817)\end{array}$ & $\begin{array}{c}-0.0837^{*} \\
(0.0493)\end{array}$ \\
\hline Post-COVID: Summer * Female & $\begin{array}{c}-0.0866 * * * \\
(0.0274)\end{array}$ & $\begin{array}{l}-0.0358 \\
(0.0440)\end{array}$ & $\begin{array}{c}-0.1233 * * * \\
(0.0348)\end{array}$ & $\begin{array}{c}0.0514 \\
(0.0538)\end{array}$ & $\begin{array}{c}-0.1705^{* * *} \\
(0.0391)\end{array}$ & $\begin{array}{c}0.0509 \\
(0.0758)\end{array}$ & $\begin{array}{c}-0.2666^{* * *} \\
(0.0450)\end{array}$ \\
\hline Post-COVID: Fall * Female & $\begin{array}{c}0.0307 \\
(0.0251)\end{array}$ & $\begin{array}{c}0.0517 \\
(0.0399)\end{array}$ & $\begin{array}{c}0.0086 \\
(0.0319)\end{array}$ & $\begin{array}{c}0.0702 \\
(0.0494)\end{array}$ & $\begin{array}{c}0.0120 \\
(0.0359)\end{array}$ & $\begin{array}{c}-0.007 \\
(0.0701)\end{array}$ & $\begin{array}{l}-0.0467 \\
(0.0413)\end{array}$ \\
\hline Personal & Yes & Yes & Yes & Yes & Yes & Yes & Yes \\
\hline Seasonality & Yes & Yes & Yes & Yes & Yes & Yes & Yes \\
\hline Time Trend & Yes & Yes & Yes & Yes & Yes & Yes & Yes \\
\hline Year FE & Yes & Yes & Yes & Yes & Yes & Yes & Yes \\
\hline State FE & Yes & Yes & Yes & Yes & Yes & Yes & Yes \\
\hline Sample Size & $1,303,917$ & 509,015 & 794,902 & 347,240 & 623,470 & 171,432 & 447,662 \\
\hline
\end{tabular}

Notes: The sample consists of all married people ages 25 to 55 . The dependent variable is the Employment to Population ratio in Panel A and is log weekly working hours on all jobs in Panel B (including zero hours for those not working and top-coded to 60 hours). Log hours are transformed with inverse hyperbolic sine to approximate logs and include zero hours. The sample period covers January 2017 to December 2020. The reference period is February 2020. Post-COVID periods include April to May 2020 for Spring, June to August 2020 for Summer, and September to December 2020 for Fall. Full interactions for March 2020 and the pre-COVID period, though not reported in the table, are included in the analysis. All specifications include full interaction terms and a constant term. All specifications also control for years of potential work experience and its square, education level, and spouse being present or absent. Specifications are estimated using CPS sample weights and robust standard errors. Standard errors in parentheses. ${ }^{*} p<0.10,{ }^{* *} p<0.05,{ }^{* * *} p<0.01$ 
Table A.6. Difference-in-Difference Estimates Relative to Men, Unmarried Sample

\begin{tabular}{|c|c|c|c|c|c|c|c|}
\hline \multirow[b]{2}{*}{ Sample: } & $(1)$ & $(2)$ & (3) & $(4)$ & $(5)$ & (6) & (7) \\
\hline & All & No kid & Any kid & $\begin{array}{c}\text { Any } \\
0-5 \text { kid }\end{array}$ & $\begin{array}{c}\text { Any } \\
6-17 \text { kid }\end{array}$ & $\begin{array}{c}\text { Only } \\
0-5 \text { kid }\end{array}$ & $\begin{array}{c}\text { Only } \\
6-17 \text { kid }\end{array}$ \\
\hline \multicolumn{8}{|c|}{ Panel A. Employment to Population Ratio } \\
\hline \multirow[t]{2}{*}{ Post-COVID: Spring * Female } & -0.0066 & -0.0078 & 0.0057 & 0.0359 & 0.0051 & 0.0045 & -0.0202 \\
\hline & $(0.0084)$ & $(0.0096)$ & $(0.0188)$ & $(0.0312)$ & $(0.0212)$ & $(0.0417)$ & $(0.0234)$ \\
\hline \multirow[t]{2}{*}{ Post-COVID: Summer * Female } & $-0.0132 *$ & -0.0139 & -0.0105 & 0.0076 & -0.0188 & 0.0017 & $-0.0354 *$ \\
\hline & $(0.0076)$ & $(0.0087)$ & $(0.0168)$ & $(0.0282)$ & $(0.0188)$ & $(0.0377)$ & $(0.0206)$ \\
\hline \multirow[t]{2}{*}{ Post-COVID: Fall * Female } & -0.0095 & -0.0038 & $-0.0246 *$ & -0.0186 & -0.0261 & -0.0286 & $-0.0354^{*}$ \\
\hline & $(0.0069)$ & $(0.0079)$ & $(0.0149)$ & $(0.0243)$ & $(0.0167)$ & $(0.0332)$ & $(0.0187)$ \\
\hline \multicolumn{8}{|c|}{ Panel B. Unconditional Hours of Work } \\
\hline \multirow[t]{2}{*}{ Post-COVID: Spring * Female } & -0.0216 & -0.0393 & 0.1146 & 0.2078 & 0.1433 & 0.0024 & 0.0257 \\
\hline & $(0.0374)$ & $(0.0428)$ & $(0.0843)$ & $(0.1374)$ & $(0.0951)$ & $(0.1844)$ & $(0.1062)$ \\
\hline \multirow[t]{2}{*}{ Post-COVID: Summer * Female } & $-0.1208 * * *$ & $-0.1136 * * *$ & -0.1231 & 0.0238 & $-0.1853 * *$ & 0.0061 & $-0.2747 * * *$ \\
\hline & $(0.0341)$ & $(0.0391)$ & $(0.0759)$ & $(0.1255)$ & $(0.0854)$ & $(0.1688)$ & $(0.0948)$ \\
\hline \multirow[t]{2}{*}{ Post-COVID: Fall * Female } & -0.0505 & -0.0257 & -0.1047 & -0.0214 & $-0.1331^{*}$ & -0.0707 & $-0.1973 * *$ \\
\hline & $(0.0308)$ & $(0.0354)$ & $(0.0669)$ & $(0.1083)$ & $(0.0755)$ & $(0.1486)$ & $(0.0848)$ \\
\hline Personal & Yes & Yes & Yes & Yes & Yes & Yes & Yes \\
\hline Seasonality & Yes & Yes & Yes & Yes & Yes & Yes & Yes \\
\hline Time Trend & Yes & Yes & Yes & Yes & Yes & Yes & Yes \\
\hline Year FE & Yes & Yes & Yes & Yes & Yes & Yes & Yes \\
\hline State FE & Yes & Yes & Yes & Yes & Yes & Yes & Yes \\
\hline Sample Size & 924,268 & 716,409 & 207,859 & 79,733 & 165,656 & 42,203 & 128,126 \\
\hline \multicolumn{8}{|c|}{$\begin{array}{l}\text { Notes: The sample consists of all unmarried people ages } 25 \text { to } 55 \text {. Unmarried sample includes people who are never married, widowed, divorced, or separated. } \\
\text { The dependent variable is the Employment to Population ratio in Panel A and is log weekly working hours on all jobs in Panel B (including zero hours for those } \\
\text { not working and top-coded to } 60 \text { hours). Log hours are transformed with inverse hyperbolic sine to approximate logs and include zero hours. The sample period } \\
\text { covers January } 2017 \text { to December } 2020 \text {. The reference period is February } 2020 \text {. Post-COVID periods include April to May } 2020 \text { for Spring, June to August } 2020 \\
\text { for Summer, and September to December } 2020 \text { for Fall. Full interactions for March } 2020 \text { and the pre-COVID period, though not reported in the table, are } \\
\text { included in the analysis. All specifications include full interaction terms and a constant term. All specifications also control for years of potential work experience } \\
\text { and its square, education level, and spouse being present or absent. Specifications are estimated using CPS sample weights and robust standard errors. Standard } \\
\text { errors in parentheses. }{ }^{*} p<0.10,{ }^{* *} p<0.05,{ }^{* *} p<0.01\end{array}$} \\
\hline
\end{tabular}


Table A.7. Difference-in-Difference Estimates Relative to Men, Employment to Population Ratio

\begin{tabular}{|c|c|c|c|c|c|c|c|}
\hline \multirow[b]{2}{*}{ Sample: } & $(1)$ & $(2)$ & (3) & (4) & (5) & (6) & (7) \\
\hline & All & No kid & Any kid & $\begin{array}{c}\text { Any } \\
0-5 \text { kid }\end{array}$ & $\begin{array}{c}\text { Any } \\
6-17 \text { kid }\end{array}$ & $\begin{array}{c}\text { Only } \\
0-5 \text { kid }\end{array}$ & $\begin{array}{c}\text { Only } \\
6-17 \text { kid }\end{array}$ \\
\hline \multirow[t]{2}{*}{ Post-COVID: Spring * Female } & -0.0046 & -0.0020 & -0.0116 & 0.0071 & $-0.0193^{*}$ & 0.0177 & $-0.0285^{* *}$ \\
\hline & $(0.0065)$ & $(0.0089)$ & $(0.0091)$ & $(0.0146)$ & $(0.0102)$ & $(0.0203)$ & $(0.0116)$ \\
\hline Post-COVID: Summer * Female & -0.0037 & 0.0033 & $-0.0139 *$ & 0.0169 & $-0.0240 * * *$ & 0.0238 & $-0.0403 * * *$ \\
\hline \multirow[t]{2}{*}{ Post-COVID: Fall * Female } & -0.0037 & -0.0030 & -0.0063 & 0.0093 & -0.0086 & 0.0005 & $-0.0202 * *$ \\
\hline & $(0.0053)$ & $(0.0073)$ & $(0.0076)$ & $(0.0121)$ & $(0.0085)$ & $(0.0170)$ & $(0.0097)$ \\
\hline \multicolumn{8}{|c|}{ Panel B. States with Low Level of In-Person Instruction } \\
\hline \multirow[t]{2}{*}{ Post-COVID: Spring * Female } & $-0.0188^{* *}$ & -0.0091 & $-0.0321 * *$ & -0.0115 & $-0.0326 * *$ & -0.0288 & $-0.0472 * * *$ \\
\hline & $(0.0090)$ & $(0.0122)$ & $(0.0131)$ & $(0.0204)$ & $(0.0148)$ & $(0.0282)$ & $(0.0170)$ \\
\hline Post-COVID: Fall * Female & $(0.0076)$ & $(0.0102)$ & $(0.0110)$ & $(0.0175)$ & $(0.0124)$ & $(0.0242)$ & $(0.0141)$ \\
\hline Personal & Yes & Yes & Yes & Yes & Yes & Yes & Yes \\
\hline Seasonality & Yes & Yes & Yes & Yes & Yes & Yes & Yes \\
\hline Time Trend & Yes & Yes & Yes & Yes & Yes & Yes & Yes \\
\hline Year FE & Yes & Yes & Yes & Yes & Yes & Yes & Yes \\
\hline State FE & Yes & Yes & Yes & Yes & Yes & Yes & Yes \\
\hline Sample Size & $1,527,876$ & 828,099 & 699,777 & 296,506 & 553,462 & 146,315 & 403,271 \\
\hline
\end{tabular}

Notes: The sample consists of all people ages 25 to 55 . States with lower degree of in-person instruction include MA, NJ, IL, DE, MD, VA, KY, NM, NV, WA, OR, CA, HI, and Washington D.C. The sample period covers January 2017 to December 2020. The reference period is February 2020. Post-COVID periods include April to May 2020 for Spring, June to August 2020 for Summer, and September to December 2020 for Fall. Full interactions for March 2020 and the pre-COVID period, though not reported in the table, are included in the analysis. All specifications include full interaction terms and a constant term. All specifications also control for years of potential work experience and its square, education level, and marital status. Specifications are estimated using CPS sample weights and robust standard errors. Standard errors in parentheses. ${ }^{*} p<0.10,{ }^{* *} p<0.05,{ }^{* * *} p<0.01$ 
Table A.8. Difference-in-Difference Estimates Relative to Men, Unconditional Hours of Work

\begin{tabular}{|c|c|c|c|c|c|c|c|}
\hline & $(1)$ & $(2)$ & (3) & (4) & $(5)$ & (6) & (7) \\
\hline Sample: & All & No kid & Any kid & $\begin{array}{c}\text { Any } \\
0-5 \text { kid }\end{array}$ & $\begin{array}{c}\text { Any } \\
\text { 6-17 kid }\end{array}$ & $\begin{array}{c}\text { Only } \\
0-5 \text { kid }\end{array}$ & $\begin{array}{c}\text { Only } \\
6-17 \text { kid }\end{array}$ \\
\hline \multicolumn{8}{|c|}{ Panel A. States with High Level of In-Person Instruction } \\
\hline Post-COVID: Spring * Female & $\begin{array}{c}0.0077 \\
(0.0291)\end{array}$ & $\begin{array}{l}-0.0048 \\
(0.0399)\end{array}$ & $\begin{array}{c}0.0070 \\
(0.0414)\end{array}$ & $\begin{array}{l}0.1076 * \\
(0.0650)\end{array}$ & $\begin{array}{l}-0.0163 \\
(0.0464)\end{array}$ & $\begin{array}{c}0.1048 \\
(0.0913)\end{array}$ & $\begin{array}{l}-0.0796 \\
(0.0530)\end{array}$ \\
\hline Post-COVID: Summer * Female & $\begin{array}{c}-0.0928 * * * \\
(0.0266)\end{array}$ & $\begin{array}{c}-0.0774 * * \\
(0.0364)\end{array}$ & $\begin{array}{c}-0.1141^{* * *} \\
(0.0378)\end{array}$ & $\begin{array}{c}0.0581 \\
(0.0598)\end{array}$ & $\begin{array}{c}-0.1611^{* * *} \\
(0.0422)\end{array}$ & $\begin{array}{c}0.0707 \\
(0.0845)\end{array}$ & $\begin{array}{c}-0.2578 * * * \\
(0.0482)\end{array}$ \\
\hline Post-COVID: Fall * Female & $\begin{array}{c}0.0018 \\
(0.0241)\end{array}$ & $\begin{array}{l}-0.0149 \\
(0.0328)\end{array}$ & $\begin{array}{c}0.0101 \\
(0.0343)\end{array}$ & $\begin{array}{c}0.1077^{* *} \\
(0.0540)\end{array}$ & $\begin{array}{l}-0.0094 \\
(0.0383)\end{array}$ & $\begin{array}{c}0.0755 \\
(0.0769)\end{array}$ & $\begin{array}{l}-0.0742^{*} \\
(0.0440)\end{array}$ \\
\hline \multicolumn{8}{|c|}{ Panel B. States with Low Level of In-Person Instruction } \\
\hline Post-COVID: Spring * Female & $\begin{array}{l}-0.0463 \\
(0.0405)\end{array}$ & $\begin{array}{l}-0.0205 \\
(0.0547)\end{array}$ & $\begin{array}{l}-0.0796 \\
(0.0591)\end{array}$ & $\begin{array}{c}0.0311 \\
(0.0915)\end{array}$ & $\begin{array}{l}-0.0792 \\
(0.0666)\end{array}$ & $\begin{array}{l}-0.0715 \\
(0.1282)\end{array}$ & $\begin{array}{c}-0.1606 * * \\
(0.0768)\end{array}$ \\
\hline Personal & Yes & Yes & Yes & Yes & Yes & Yes & Yes \\
\hline Seasonality & Yes & Yes & Yes & Yes & Yes & Yes & Yes \\
\hline Time Trend & Yes & Yes & Yes & Yes & Yes & Yes & Yes \\
\hline Year FE & Yes & Yes & Yes & Yes & Yes & Yes & Yes \\
\hline State FE & Yes & Yes & Yes & Yes & Yes & Yes & Yes \\
\hline Sample Size & $1,527,876$ & 828,099 & 699,777 & 296,506 & 553,462 & 146,315 & 403,271 \\
\hline
\end{tabular}

Notes: The sample consists of all people ages 25 to 55 . States with lower degree of in-person instruction include MA, NJ, IL, DE, MD, VA, KY, NM, NV, WA, OR, CA, HI, and Washington D.C. The sample period covers January 2017 to December 2020. The reference period is February 2020. Post-COVID periods include April to May 2020 for Spring, June to August 2020 for Summer, and September to December 2020 for Fall. Full interactions for March 2020 and the pre-COVID period, though not reported in the table, are included in the analysis. All specifications include full interaction terms and a constant term. All specifications also control for years of potential work experience and its square, education level, and marital status. Specifications are estimated using CPS sample weights and robust standard errors. Standard errors in parentheses. ${ }^{*} p<0.10,{ }^{* *} p<0.05,{ }^{* * *} p<0.01$ 